\title{
The influence of cloudiness and atmospheric circulation on radiation balance and its components
}

\author{
Marek Kejna ${ }^{1}$ (D) - Joanna Uscka-Kowalkowska ${ }^{1}$ (D) Paweł Kejna ${ }^{2}$. \\ Received: 12 May 2020 / Accepted: 16 February 2021 / Published online: 1 March 2021 \\ (C) The Author(s) 2021
}

\begin{abstract}
The article contains an analysis of the influence of cloudiness and atmospheric circulation on the components of radiation balance (Q*) using the example of measurements taken in an extra-urban area of Koniczynka near Torun (Central Poland) in the years 2011-2018. The average annual value of Q* was $1,818.5 \mathrm{MJ} \cdot \mathrm{m}^{-2}$ with a maximum of $352.3 \mathrm{MJ} \cdot \mathrm{m}^{-2}$ in June, and negative values from November to January (December: ${ }^{-} 27.4 \mathrm{MJ} \cdot \mathrm{m}^{-2}$ ). The shortwave radiation balance (S*) amounted to $3,129.2 \mathrm{MJ} \cdot \mathrm{m}^{-2}$ and the longwave radiation balance $\left(\mathrm{L}^{*}\right)$ was $1,310.7 \mathrm{MJ} \cdot \mathrm{m}^{-2}$. In June the average solar irradiance $(\mathrm{S} \downarrow)$ at midday was $600 \mathrm{~W} \cdot \mathrm{m}^{-2}$. The natural annual and diurnal course of $\mathrm{Q}^{*}$ components, determined by astronomical factors, is disturbed by changes in cloudiness and inflow of various air masses. It has been found that an increase in cloudiness causes the amount of incoming solar radiation $(\mathrm{S} \downarrow)$ to fall, thus decreasing the $\mathrm{S}^{*}$ balance. Moreover, clouds restrict longwave radiation balance ( $\mathrm{L}^{*}$ ), in particular, downward atmospheric radiation $(\mathrm{L} \downarrow)$ increases. The opposite relationships of $\mathrm{S}^{*}$ and $\mathrm{L}^{*}$ affect $\mathrm{Q}^{*}$ in individual months. The components of $\mathrm{Q}^{*}$ are influenced by atmospheric circulation; it has been observed that anticyclonic types, characterised by smaller cloud amounts, favour a greater influx of $(\mathrm{S} \downarrow)$ and — at the same time — greater emittance (L $\uparrow)$; however, $\mathrm{Q}^{*}$ is then greater than in the case of cyclonic circulation. A statistically significant trend of $\mathrm{Q}^{*}$ and its components has not been ascertained. A notable great year-on-year variability of Q*, ranging from $1,640.4 \mathrm{MJ} \cdot \mathrm{m}^{-2}$ (in 2011) to $2,081.6 \mathrm{MJ} \cdot \mathrm{m}^{-2}$ (in 2018), affects the environment. The changes are related to the cloudiness and the frequency of occurrence of different atmospheric circulation types. The role of snow cover is also important as snow reflects solar radiation which leads to the decrease of $\mathrm{S}^{*}$ andas a result — to a negative value of $Q^{*}$ in winter.
\end{abstract}

\section{Introduction}

Solar energy reaching Earth affects the functioning of the global climate system (Lockwood 2012). The radiation balance of Earth's surface $\left(\mathrm{Q}^{*}\right)$ consists of shortwave radiation balance $\left(\mathrm{S}^{*}\right)$ and longwave radiation balance $\left(\mathrm{L}^{*}\right)$, and is described by formulas (Oke 1996; Paszyński et al. 1999, etc.).

$$
\begin{gathered}
\mathrm{Q}^{*}=\mathrm{S}^{*}+\mathrm{L}^{*} ; \mathrm{S} *=\mathrm{S} \downarrow-\mathrm{S} \uparrow ; \mathrm{L} *=\mathrm{L} \downarrow-\mathrm{L} \uparrow \\
\mathrm{Q}^{*}=(\mathrm{S} \downarrow-\mathrm{S} \uparrow)+(\mathrm{L} \downarrow-\mathrm{L} \uparrow)
\end{gathered}
$$

Marek Kejna

marek.kejna@umk.pl

1 Department of Meteorology and Climatology, Faculty of Earth Sciences and Spatial Management Nicolaus Copernicus University Toruń Poland

2 Toruń, Poland where:

Q* net radiation balance,

$\mathrm{S}^{*}$ net shortwave solar radiation,

$\mathrm{L}^{*}$ net longwave solar radiation,

$\mathrm{S} \downarrow \quad$ incoming shortwave solar radiation (direct and diffuse),

$\mathrm{S} \uparrow \quad$ outgoing shortwave solar radiation, reflected by the active surface,

$\mathrm{L} \downarrow$ incoming longwave radiation,

$\mathrm{L} \uparrow \quad$ outgoing longwave radiation, emitted by the surface.

On the basis of data contained in the Baseline Surface Radiation Network, satellite observations and results obtained from global climate models, Wild et al. (2019) stated that for a clear-sky atmosphere the average intensity of $\mathrm{S} \downarrow$ is $247 \mathrm{Wm}^{-2}$, whereas in the case of $\mathrm{L} \downarrow$ it is $314 \mathrm{Wm}^{-2}$. At an average albedo of $13.5 \%, \mathrm{~S}^{*}$ is $287 \mathrm{Wm}^{-2}$, of which 214 $\mathrm{Wm}^{-2}$ is absorbed by Earth's surface and $73 \mathrm{Wm}^{-2}$ by the atmosphere.

Due to changes in the angle of solar rays caused by the rotational motion of planet Earth and its revolution around 
the Sun, the components of Q* change on both a diurnal and annual cycle. In addition, cloudiness and atmospheric extinction of radiation influence the components. $\mathrm{S} \downarrow$ reaches Earth's surface in the form of direct and diffuse radiation. In Poland, diffuse radiation typically makes up $51 \%$ of the total solar radiation: approx. $41 \%$ in summer and up to $61 \%$ in winter (Kleniewska et al. 2018). The quantity of $\mathrm{S} \downarrow$ is determined not only by the angle of solar rays, but also by the optical properties of the atmosphere, mainly cloudiness and water vapour and aerosol content in the air (Yu et al. 2006).

The absorption of solar radiations depends on the reflective properties of the surface describe by its albedo (A).

$A=\frac{\mathrm{S} \uparrow}{\mathrm{S} \downarrow} \cdot 100 \%$

The value of A depends on the type of surface, its vegetation cover and the occurrence of snow cover (e.g. Bryś 2009; Caputa and Leśniok 2009).

When it is heated, Earth's surface emits longwave radiation (L $\uparrow$ ) whose intensity depends on the surface temperature. For example, in Wrockaw (southern Poland) in the period 20072019 the mean monthly values of $\mathrm{L} \uparrow$ in January were 309.0 $\mathrm{Wm}^{-2}$ for bare soil and $309.8 \mathrm{Wm}^{-2}$ for grassy surface, and in July respectively 435.8 and $425.0 \mathrm{Wm}^{-2}$ (Bryś et al. 2020).

That upward radiation is largely absorbed by the atmosphere and returned to Earth's surface as downward atmospheric radiation $(L \downarrow)$ ), increasing the heat resources of the planet (Mlynczak et al. 2011). Generally, energy income and losses $\left(\mathrm{Q}^{*}\right)$ depend on $\mathrm{S}^{*}$ and $\mathrm{L}^{*}$, which are in turn considerably affected by cloudiness connected with the advection direction and type of incoming air masses (Bryś and Bryś 2019).

In Poland, actinometric measurements were started by W. Gorczyński in Warsaw in the year 1900. Soon after, the observations included other locations (UsckaKowalkowska 2010). The radiation balance, Q*, was measured using net radiometers or was worked out on the basis of individual radiation fluxes. In 1966, the spatial distribution of $\mathrm{Q}^{*}$ in Poland was developed based on formulas considering various meteorological elements and the properties of the surface and atmosphere. The obtained results were presented in Atlas of Radiation Balance in Poland (Paszyński 1966) and in an extensive article (Miara et al. 1987). The radiation resources absorbed in the area of Poland were analysed by Kozłowska-Szczęsna (1973). Based on the energy exchange between atmosphere and surface, Paszyński et al. (1999) developed a method of topoclimatic surveying. The introduction of modern measurement instruments enabled continuous registration of the components of Q*, for instance in Kraków (Olecki 1986) Wrocław (Bryś and Bryś 2003, 2007; Bryś 2013; Bryś et al. 2019, 2020), Sosnowiec (Budzik 2006; Caputa and Leśniok 2009) and Łódź (Podstawczyńska 2007; Fortuniak et al. 2015). In Toruń, studies of solar climate were conducted by Wójcik (1996) and Uscka (2004), focusing mainly on the transmission of solar radiation by the atmosphere. The spatial distribution of $\mathrm{S} \downarrow$ in the city was also studied (Kejna et al. 2014a, b). In the suburban zone of the city of Torun, at Koniczynka, measurements of $\mathrm{S} \downarrow$ were launched in 2001 as part of the Integrated Environmental Monitoring Programme (Kejna and Uscka-Kowalkowska 2018a), and since 2011, they have been extended to include measurements of $\mathrm{Q}^{*}$ (Kejna et al. 2014a, b).

The purpose of this article is to analyse the influence of cloudiness and atmospheric circulation on the components of radiation balance at Koniczynka (Central Poland) in the years 2011-2018. Atmospheric circulation is one of the most vital climate influencing factors. Through advection of various air masses, it directly affects the thermal conditions and precipitation in a given area. It also indirectly determines (the presence of clouds and aerosols) the amount of solar energy reaching the earth's surface and the balance of long-wave radiation. Recognising the influence of cloudiness and the impact of various types of synoptic situations is crucial in understanding recent climate change (Kejna and Rudzki 2021).

\section{Observations area and methodology}

Actinometric measurements were conducted at the Integrated Environmental Monitoring Station at Koniczynka, located north of Torun, in the Chełmno Lakeland of Central Poland ( $\varphi=53^{\circ} 05^{\prime} \mathrm{N}, \lambda=18^{\circ} 42^{\prime} \mathrm{E}, \mathrm{h}=84 \mathrm{~m}$ a.s.l.). The station is situated on an intensively farmed, early-glacial, flat moraine plain of the last ice age (Wójcik and Marciniak 1996; Kejna and Uscka-Kowalkowska 2018b).

The observation site is located on open ground and, to the NE only, the horizon was blocked by the trees of a nearby park, especially at low solar elevation angles (Fig. 1). The sky view factor (SVF) of the measurement site was 0.97 (Kejna et al. 2014a, b). The solar altitude at Koniczynka at midday ranges from $12^{\circ} 28^{\prime}$ on 22 December to $60^{\circ} 22^{\prime}$ on 22 June, and the length of day reaches from $7 \mathrm{~h} 33 \mathrm{~min}$ to $16 \mathrm{~h} 56 \mathrm{~min}$.

The components of $\mathrm{Q}^{*}$ were registered using a Kipp\&Zonen CNR 4 net radiometer. The instrument, according to the manufacturer's specifications (www.kippzonen. com), consists of a pair of pyranometers (for $\mathrm{S} \downarrow$ and $\mathrm{S} \uparrow$ ) with a spectral range of 300 to $2,800 \mathrm{~nm}$, and two pyrgeometers (for $\mathrm{L} \uparrow$ and $\mathrm{L} \downarrow$ ) with a range of 4,500 to $42,000 \mathrm{~nm}$, facing upwards and downwards. The CNR 4 was positioned $2 \mathrm{~m}$ above grassy ground (Fig. 2). In winter, snow cover appeared and greatly altered the surface albedo. The albedo was calculated at an intensity of $\mathrm{Sd} \geq 70 \mathrm{Wm}^{-2}$. The radiometer was custom calibrated and ventilated, which 
Fig. 1 a Meteorological station at Koniczynka. b The obstruction of the horizon and the Sun's path on $21 \mathrm{March} / 23 \mathrm{September}$ and 22 June and 22 December in

Koniczynka (according to Kejna et al. 2014a, b)

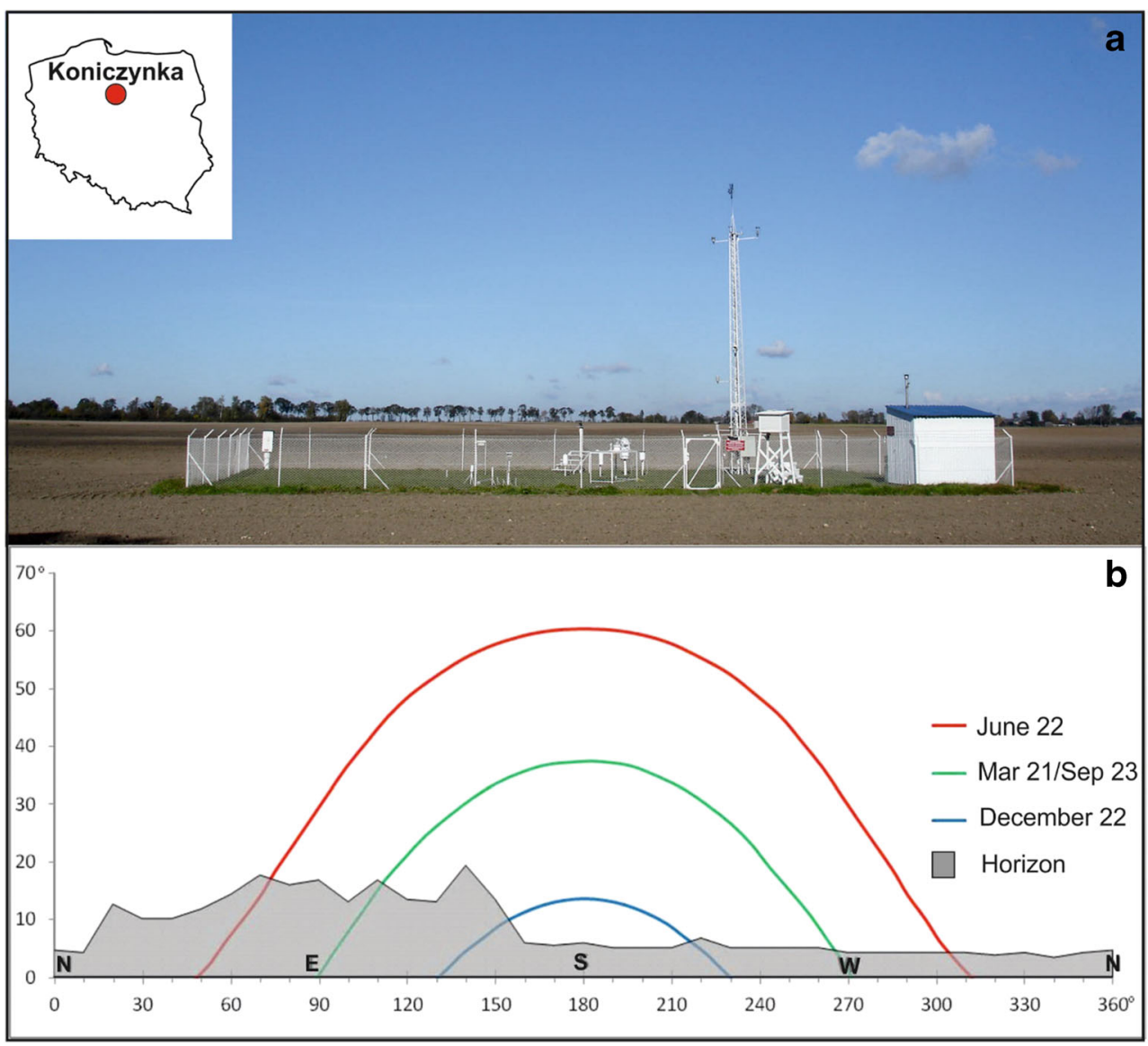

prevented accumulation of atmospheric deposits, precipitation and dust on the domes.

The radiation balance components were recorded at 10 minute intervals in 2011-2018. There were occasional gaps in the data series, resulting from equipment faults or power shortages. The missing data $(13.1 \%)$ was supplemented by linear regression on the basis of parallel measurements carried out at a nearby Meteorological Observatory of the Nicolaus Copernicus University in Torun (9 km away). A general meteorological background of the observational period was described using data from automatic weather stations installed at
Koniczynka. Until 2016, a Milos 500 station was used, which was then replaced with MAWS301.

The article provides an analysis of the relationship between Q* components on the one hand, and atmospheric circulation, type of barometric pressure centre and direction of air advection on the other. Accordingly, based on 12:00 UTC weather charts published by the Institute of Meteorology and Water Management (http://www.pogodynka.pl), the type of synoptic situation was determined for each day using the subjective classification proposed by Niedźwiedź (1981). It distinguishes 21 types, established for different advection directions
Fig. 2 Net Radiometer CNR 4 at Koniczynka
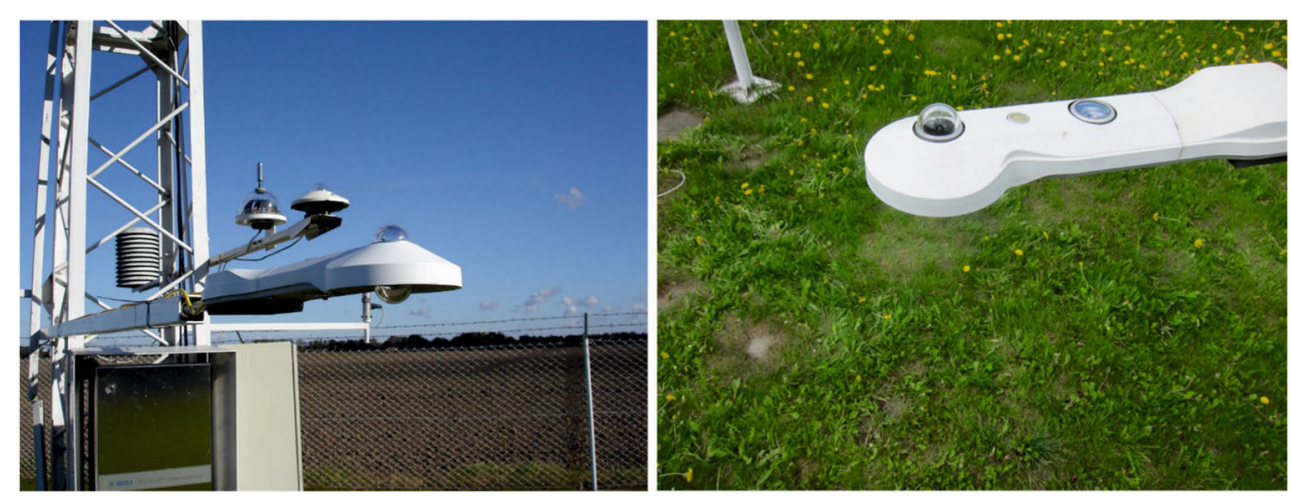
according to the eight-point wind rose, divided into anticyclonic (a) and cyclonic (c) patterns. Anticyclone (Ca) and cyclone $(\mathrm{Cc})$ centres were identified along with an anticyclonic wedge (Ka) and a cyclonic trough $(\mathrm{Bc})$. Non-classifiable patterns and barometric situations were marked with an "X".

The article also analyses the correlation of $Q^{*}$ components and the degree of cloudiness. The cloud cover data (on a scale of 0-8) was obtained from a nearby (approx. $9 \mathrm{~km}$ away) weather station of the Institute of Meteorology and Water Management in the Torun (https://danepubliczne.imgw.pl). Cloud cover was observed every hour.

\section{Results}

\subsection{Meteorological conditions in 2011-2018}

The Koniczynka station is representative of the climate of Central Poland. Due to its location in an agricultural area, no direct anthropogenic influences typical of an urban climate are observable there. The average degree of cloudiness at Torun was 5.2 on a scale of 0 to 8 (Table 1). The greatest amount of clouds was observed in 2017 (5.7) and the smallest (4.8) in 2011 and again in 2018. The sunshine duration was quite changeable, ranging from $1,593.8$ hours in 2016 to $2,134.2$ hours in 2018, with a mean duration of $1,757.3 \mathrm{~h}$ (UsckaKowalkowska et al. 2015). The analysed years were exceptionally warm and the mean annual air temperature reached $8.1^{\circ} \mathrm{C}$ in 2013 and $9.9^{\circ} \mathrm{C}$ in 2014 . The relative humidity of air was high, averaging 79\%, and ranging from $74 \%$ in 2011 and 2012 to $85 \%$ in 2017 . The precipitation varied considerably from one year to another and ranged from $437.3 \mathrm{~mm}$ in 2015 to $727.2 \mathrm{~mm}$ in 2017 . The mean pressure reduced to sea level was $1,015.2 \mathrm{hPa}$ and the mean wind speed at Koniczynka was a moderate $3.3 \mathrm{~ms}^{-1}$. None of these values differed significantly from their long-term means (Kejna and Uscka-
Kowalkowska 2018a), so they can be considered as representative of the area.

\subsection{Solar radiation}

The global solar radiation $\mathrm{S} \downarrow$ reaching the ground At Koniczynka in the years 2011-2018 exhibited a certain variability determined by the angle of solar rays and the length of day (Fig. 3). The pattern of $\mathrm{S} \downarrow$ showed a sizeable influence of cloudiness and other factors, restricting the quantity of radiation reaching the surface.

In the analysed period, the mean intensity of $\mathrm{S} \downarrow$ amounted to $122.6 \mathrm{~W} \cdot \mathrm{m}^{-2}$, which gives $3,865.2 \mathrm{MJ} \cdot \mathrm{m}^{-2}$ of energy during the year (Table 2). In the annual course, the highest intensity of $\mathrm{S} \downarrow$ was observed in June $\left(235.0 \mathrm{~W} \cdot \mathrm{m}^{-2}\right)$ and May $\left(225.6 \mathrm{~W} \cdot \mathrm{m}^{-2}\right)$, whereas the lowest occurred in December $\left(16.3 \mathrm{~W} \cdot \mathrm{m}^{-2}\right)$. The maximum recorded values of $\mathrm{S} \downarrow$ reached $1,139.2 \mathrm{~W} \cdot \mathrm{m}^{-2}$ in June, but in December, they did not exceed $300 \mathrm{~W} \cdot \mathrm{m}^{-2}$. The diurnal sums of $\mathrm{S} \downarrow$ were greater than $30 \mathrm{MJ}$. $\mathrm{m}^{-2}$ at the summer solstice, though in December they did not even reach $1 \mathrm{MJ} \cdot \mathrm{m}^{-2}$.

The mean intensity of reflected radiation $(\mathrm{S} \uparrow$ ) was $23.4 \mathrm{~W}$. $\mathrm{m}^{-2}$, which corresponds to a loss of $737.1 \mathrm{MJ} \cdot \mathrm{m}^{-2}$ of energy during the year. In the annual course, the greatest values of $\mathrm{S} \uparrow$ were noted in May and June (over $40 \mathrm{~W} \cdot \mathrm{m}^{-2}$ ), and the smallest in December $\left(3.7 \mathrm{~W} \cdot \mathrm{m}^{-2}\right)$.

The relationship between $\mathrm{S} \uparrow$ and $\mathrm{S} \downarrow$ is described by the albedo (A). In winter months, A reached $80-90 \%$ while snow cover persisted (Fig. 4). The number of days with snow cover ranged from 15 in 2015 to 68 in 2013. By contrast, the albedo of grassy surfaces amounted to $17-19 \%$ in the other months.

The mean annual shortwave radiation balance $\left(\mathrm{S}^{*}\right)$ was $3,129.2 \mathrm{MJ} \cdot \mathrm{m}^{-2}$, and the greatest income of solar radiation was observed in June $\left(502.3 \mathrm{MJ} \cdot \mathrm{m}^{-2}\right.$ ) and May (493.1 MJ. $\mathrm{m}^{-2}$ ) - Table 2. In winter, the December and January balances were $34.1 \mathrm{MJ} \cdot \mathrm{m}^{-2}$ and $36.3 \mathrm{MJ} \cdot \mathrm{m}^{-2}$, respectively. However, the solar radiation balance $\mathrm{S}^{*}$ is, essentially,
Table 1 Yearly values of meteorological elements at Koniczynka in the years 20112018

\begin{tabular}{llllllll}
\hline Years & $\mathrm{C}(0-8)$ & $\mathrm{SD}$ (hours) & $\mathrm{T}\left({ }^{\circ} \mathrm{C}\right)$ & $\mathrm{f}(\%)$ & $\mathrm{P}(\mathrm{mm})$ & $\mathrm{AP}(\mathrm{hPa})$ & $\mathrm{V}\left(\mathrm{ms}^{-1}\right)$ \\
\hline 2011 & 4.8 & 1781.6 & 8.4 & 74 & 647.2 & 1014.9 & 3.5 \\
2012 & 5.2 & 1818.5 & 8.9 & 74 & 484.2 & 1015.2 & 3.5 \\
2013 & 5.5 & 1595.4 & 8.1 & 77 & 618.6 & 1014.4 & 3.1 \\
2014 & 5.2 & 1792.2 & 9.9 & 81 & 463.9 & 1014.6 & 3.2 \\
2015 & 5.2 & 1711.1 & 9.4 & 80 & 437.3 & 1016.2 & 3.3 \\
2016 & 5.4 & 1593.8 & 9.8 & 83 & 542.3 & 1015.3 & 3.3 \\
2017 & 5.7 & 1631.8 & 8.5 & 85 & 727.2 & 1016.0 & 3.2 \\
2018 & 4.8 & 2134.2 & 9.8 & 78 & 455.8 & 1014.7 & 3.0 \\
$2011-2018$ & 5.2 & 1757.3 & 9.1 & 79 & 547.1 & 1015.2 & 3.3 \\
\hline
\end{tabular}

$C$ cloudiness in Torun, $S D$ sunshine duration, $T$ air temperature, $f$ relative air humidity, $P$ precipitation, $A P$ air pressure at the station level, $V$ wind velocity 


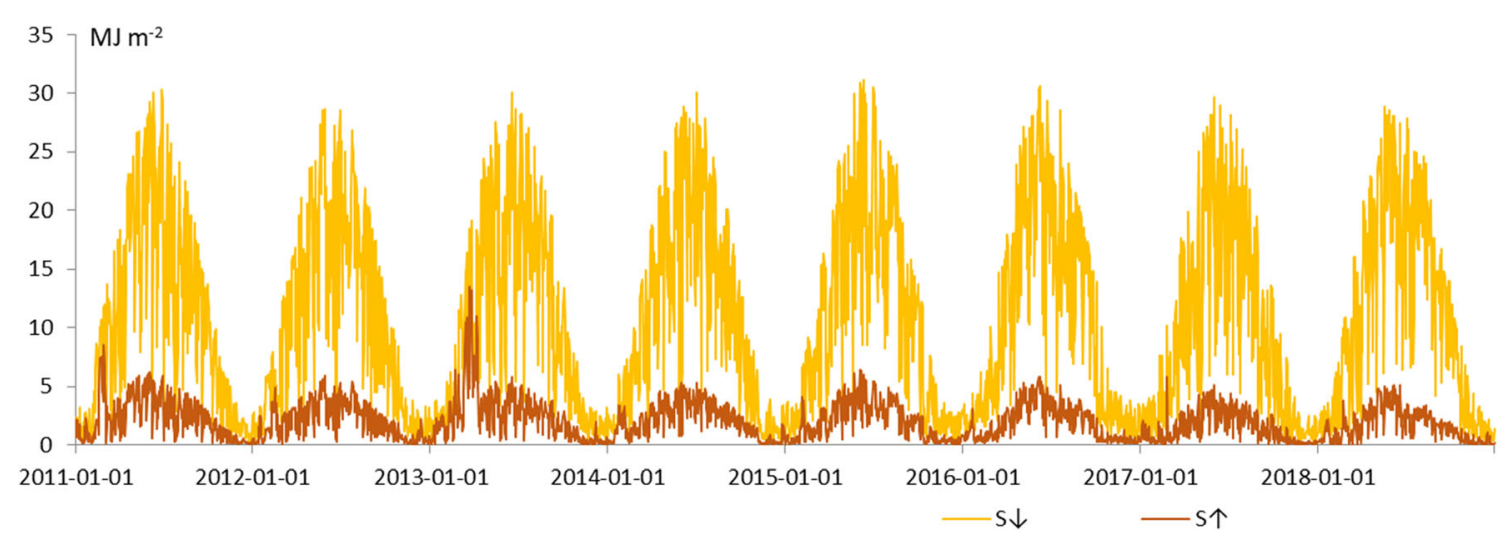

Fig. 3 Course of daily sums of solar radiation ( $\mathrm{S} \downarrow$ ) and reflected solar radiation ( $\mathrm{S} \uparrow$ ) at Koniczynka in the years 2011-2018

affected not only by the incoming solar radiation $(\mathrm{S} \downarrow)$ and state of atmosphere but also on the reflective properties of the surface described by its albedo (A).

\subsection{Incoming and outgoing longwave radiation}

Once it has absorbed solar radiation, Earth's surface becomes warmer and emits longwave radiation $(\mathrm{L} \uparrow)$. Its intensity depends on the temperature of the ground. That is why $\mathrm{L} \uparrow \mathrm{dem}-$ onstrates a clear annual pattern (Fig. 5).

The mean intensity of $\mathrm{L} \uparrow$ was $362.2 \mathrm{~W} \cdot \mathrm{m}^{-2}$, and as much as $11,422.3 \mathrm{MJ} \cdot \mathrm{m}^{-2}$ of energy was emitted over a year (Table 2). The highest intensity of $\mathrm{L} \uparrow$ was observed in June $\left(418 \mathrm{~W} \cdot \mathrm{m}^{-2}\right)$, July and August $\left(415.5 \mathrm{~W} \cdot \mathrm{m}^{-2}\right.$ and $409.6 \mathrm{~W}$. $\mathrm{m}^{-2}$, respectively), when the ground temperature reaches its highest values. In winter, the intensity of $\mathrm{L} \uparrow$ is lowest (307.7 $\mathrm{W} \cdot \mathrm{m}^{-2}$ in January). The atmosphere absorbs a great portion of the longwave radiation and becomes a secondary source of its emission. Some of the radiation comes back to the surface.
The mean intensity of the downward radiation $\mathrm{L} \downarrow$ was 320.6 $\mathrm{W} \cdot \mathrm{m}^{-2}$, which makes an income of $10,110.8 \mathrm{MJ} \cdot \mathrm{m}^{-2}$ over a year. The greatest value of $\mathrm{L} \downarrow$ was noted in June $(364.1 \mathrm{~W}$. $\left.\mathrm{m}^{-2}\right)$, and the smallest in January $\left(284.7 \mathrm{~W} \cdot \mathrm{m}^{-2}\right)$. The longwave radiation balance was negative and averaged $-1,310.7 \mathrm{MJ} \cdot \mathrm{m}^{-2}$ annually. The greatest loss of radiation occurred in May $\left(-153.8 \mathrm{MJ} \cdot \mathrm{m}^{-2}\right)$.

\subsection{Solar radiation balance}

The radiation balance $\left(\mathrm{Q}^{*}\right)$ comprises the shortwave radiation balance $\left(\mathrm{S}^{*}\right)$ and the longwave balance $\left(\mathrm{L}^{*}\right)$ and displays a distinct annual course (Fig. 6).

The mean radiation balance $\left(\mathrm{Q}^{*}\right)$ amounted to $1,818.5 \mathrm{MJ}$. $\mathrm{m}^{-2}$. In the annual course, the greatest energy income was observed in June (353.3 MJ.m ${ }^{-2}$ ), May and July (229.3 MJ. $\mathrm{m}^{-2}$ and $334.7 \mathrm{MJ} \cdot \mathrm{m}^{-2}$, respectively). From November to January, $Q^{*}$ was negative and the greatest losses of energy were observed in December $\left(-27.4 \mathrm{MJ} \cdot \mathrm{m}^{-2}\right)$.

Table 2 Mean values of radiation intensity of radiation balance components and sums of radiation balance at Koniczynka in the years 2011-2018

\begin{tabular}{llllllllll}
\hline Months & $\mathrm{S} \downarrow_{\max }\left[\mathrm{W} \cdot \mathrm{m}^{-2}\right]$ & $\mathrm{S} \downarrow\left[\mathrm{W} \cdot \mathrm{m}^{-2}\right]$ & $\mathrm{S} \uparrow\left[\mathrm{W} \cdot \mathrm{m}^{-2}\right]$ & Albedo $[\%]$ & $\mathrm{L} \uparrow\left[\mathrm{W} \cdot \mathrm{m}^{-2}\right]$ & $\mathrm{L} \downarrow\left[\mathrm{W} \cdot \mathrm{m}^{-2}\right]$ & $\mathrm{S}^{*}\left[\mathrm{MJ} \cdot \mathrm{m}^{-2}\right]$ & $\mathrm{L}^{*}\left[\mathrm{MJ} \cdot \mathrm{m}^{-2}\right]$ & $\mathrm{Q}^{*}\left[\mathrm{MJ} \cdot \mathrm{m}^{-2}\right]$ \\
\hline $\mathrm{J}$ & 410.4 & 23.1 & 9.7 & 41 & 307.7 & 284.7 & 36.3 & -61.5 & -25.2 \\
$\mathrm{~F}$ & 573.3 & 56.8 & 18.3 & 30 & 314.0 & 280.5 & 93.8 & -81.6 & 12.2 \\
$\mathrm{M}$ & 823.2 & 106.1 & 26.0 & 22 & 330.2 & 288.1 & 214.5 & -112.8 & 101.7 \\
A & 985.9 & 172.5 & 33.4 & 19 & 361.3 & 311.0 & 360.6 & -130.4 & 230.2 \\
M & 1102.2 & 225.6 & 41.5 & 18 & 394.7 & 337.2 & 493.1 & -153.8 & 339.3 \\
$\mathrm{~J}$ & 1139.2 & 235.0 & 41.2 & 18 & 418.2 & 360.4 & 502.3 & -150.0 & 352.3 \\
J & 1137.5 & 211.2 & 34.7 & 17 & 415.5 & 364.1 & 472.7 & -136.7 & 334.7 \\
A & 1030.4 & 194.3 & 32.4 & 17 & 409.6 & 357.4 & 433.7 & -139.9 & 293.8 \\
S & 867.4 & 131.3 & 22.4 & 17 & 384.0 & 336.4 & 282.3 & -123.3 & 159.0 \\
O & 687.5 & 68.2 & 12.3 & 18 & 350.4 & 314.5 & 150.1 & -96.2 & 54.0 \\
N & 459.9 & 26.0 & 4.4 & 17 & 335.1 & 310.8 & 56.2 & -63.1 & -6.9 \\
D & 314.8 & 16.3 & 3.7 & 22 & 320.8 & 297.8 & 34.1 & -61.6 & -27.4 \\
Year & 1139.2 & 122.6 & 23.4 & 21 & 362.2 & 320.6 & 3129.2 & -1310.7 & 1818.5 \\
\hline
\end{tabular}




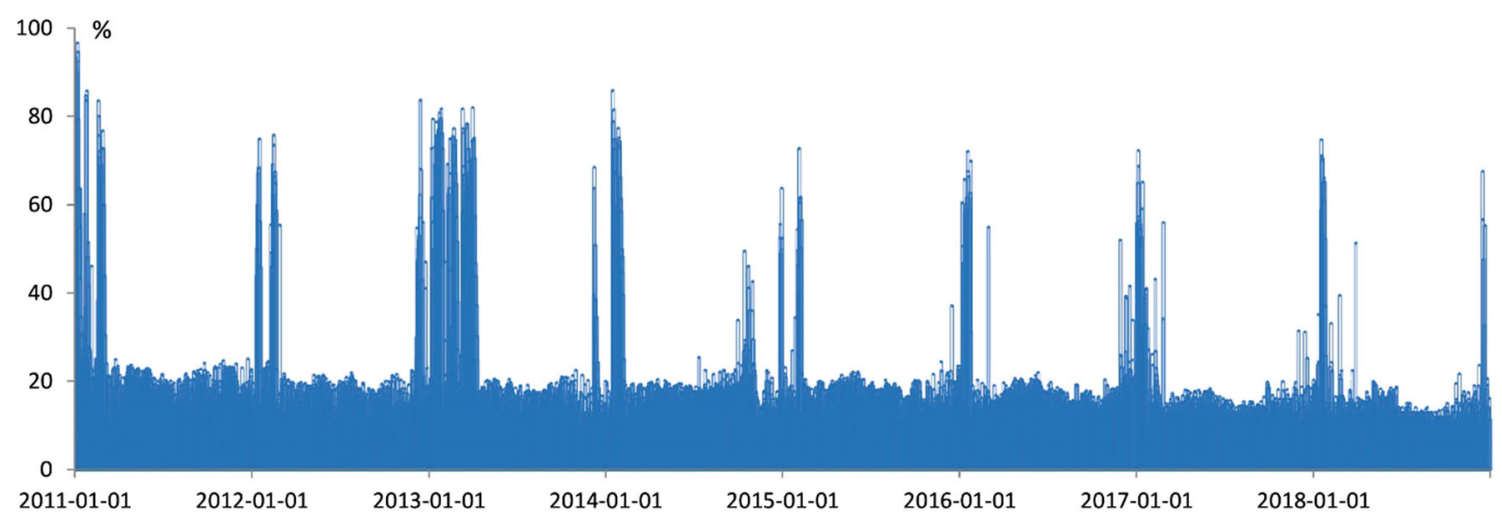

Fig. 4 Course of albedo at Koniczynka in the years 2011-2018

\subsection{The diurnal course of radiation balance components}

There is a distinct regularity in the diurnal course of the radiation balance components, connected with the rotation of the globe which, in turn, changes the sun's position above the horizon and determines the day-night sequence. There are evident differences in the diurnal course of the components of $Q^{*}$ during the year (Fig. 7). The regular diurnal course of solar radiation components controlled by astronomical factors is disturbed by atmospheric factors, mainly such as the presence of clouds, water vapour and aerosol amount.

The diurnal distribution of the individual components of Q* et Koniczynka in the period 2001-2018 was asymmetrical to the solar noon. On average, the annual intensity of $\mathrm{S} \downarrow$ at noon was $366.1 \mathrm{~W} \cdot \mathrm{m}^{-2}$, and in the case of $\mathrm{S} \uparrow$, it was $70.4 \mathrm{~W}$. $\mathrm{m}^{-2}$, so the balance $\mathrm{S}^{*}$ amounted to $295.7 \mathrm{~W} \cdot \mathrm{m}^{-2}$. In the afternoon, a decrease in $\mathrm{S} \downarrow$ was observed due to the development of cumulus clouds, at 3 p.m. the difference was $17.4 \%$. This resulted in lower $\mathrm{S} \uparrow$ and $\mathrm{S}^{*}$ values (at 3 p.m. by $18.9 \%$ ).

The intensity of long-wave radiation depends on the temperature of the emitting surface. In Koniczynka, the intensity of $\mathrm{L} \uparrow$ was $389.8 \mathrm{~W} \cdot \mathrm{m}^{-2}$, while for $\mathrm{L} \downarrow$ it was $334.5 \mathrm{~W} \cdot \mathrm{m}^{-2}$, which means that $\mathrm{L}^{*}$ was negative $\left(-55.3 \mathrm{~W} \cdot \mathrm{m}^{-2}\right)$. Due to the higher ground temperature in the afternoon, the intensity of $\mathrm{L} \uparrow$ was higher than in the symmetrical hours before noon, the difference at 3 p.m. was $33.9 \%$. In the case of $L \downarrow$, the difference was not so significant $(9.2 \%)$. L* indicates higher losses in the afternoon which amount to $4.9 \%$.

The balance of Q from 5.40 a.m. to 5.30 p.m. was positive and reached a maximum of $231.2 \mathrm{~W} \cdot \mathrm{m}^{-2}$ at noon. During night hours, $Q^{*}$ was negative and, for example, at midnight $\mathrm{Q}^{*}$ was $-31.0 \mathrm{~W} \cdot \mathrm{m}^{-2}$ due to greater losses in longwave radiation $\left(\mathrm{L} \uparrow=-343.6 \mathrm{~W} \cdot \mathrm{m}^{-2}\right)$ than the energy income from downward atmospheric radiation $\left(\mathrm{L} \downarrow=312.6 \mathrm{~W} \cdot \mathrm{m}^{-2}\right)$. In the diurnal course of $\mathrm{Q}^{*}$, higher values were observed before noon. For example, at 9 a.m., they were $25.5 \%$ higher than at 3 p.m. During the year, considerable variation in the components of $Q^{*}$ was observed. In June, from 4.30 a.m. to 7.00 p.m. $Q^{*}$ was positive and reached a maximum at noon $(577.8$ $\left.\mathrm{W} \cdot \mathrm{m}^{-2}\right)$, but at night energy losses prevailed. In winter (December), energy fluxes were minor, and positive values of $\mathrm{Q}^{*}$ were noted between 8.50 a.m. and 2.00 p.m. when the sun was at its highest (on average, $81.6 \mathrm{~W} \cdot \mathrm{m}^{-2}$ at noon). The most noticeable asymmetry in the course of individual components of $Q^{*}$ occurred in summer.

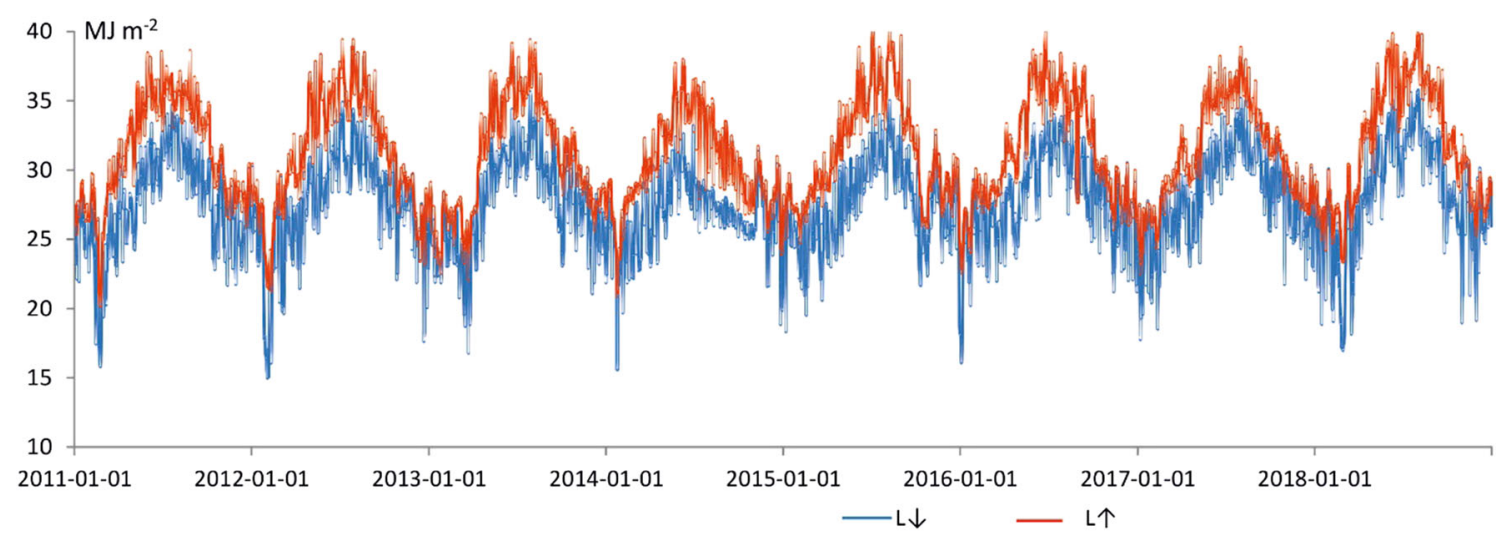

Fig. 5 Course of daily sums of incoming $(\mathrm{L} \downarrow)$ and outgoing $(\mathrm{L} \uparrow)$ longwave radiation at Koniczynka in the years 2011-2018 


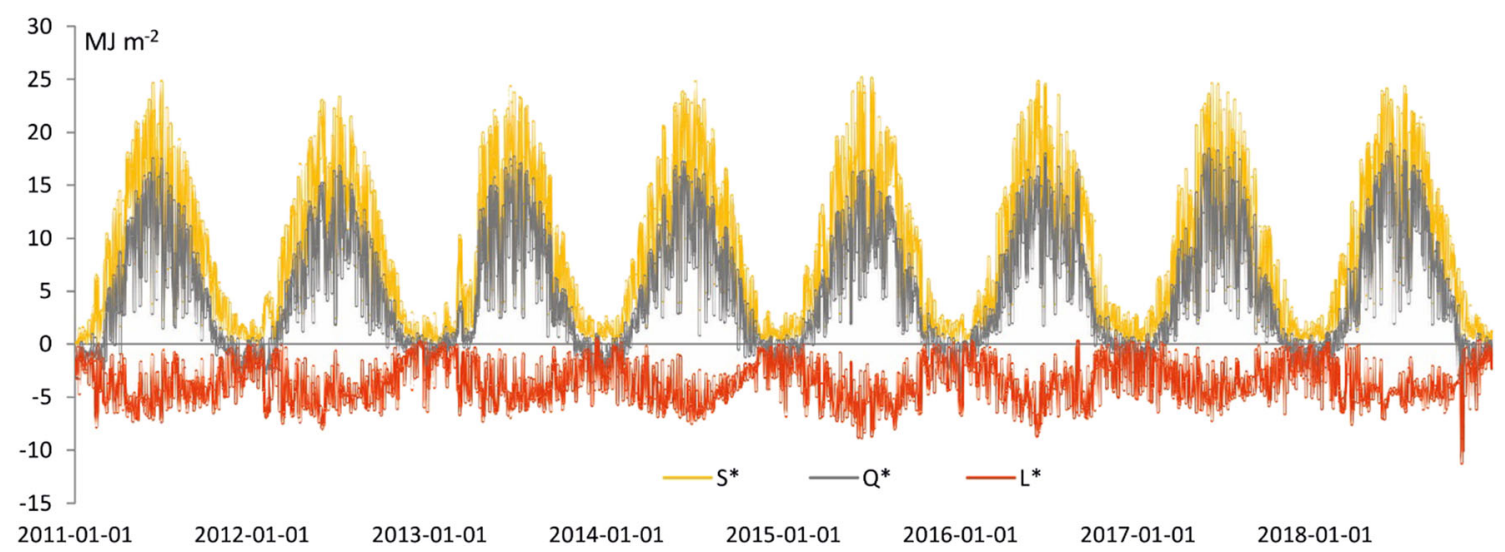

Fig. 6 Course of the short wave (S*), longwave (L*) and total (Q*) radiation balance in Koniczynka in the years 2011-2018

\subsection{The influence of cloudiness on radiation balance}

The impact of cloudiness on the radiation balance components in Koniczynka was analysed on the basis of data from Torun, where visual observations of cloud cover are made. Cloud cover is a very variable meteorological element. Nevertheless, the distance of approx. $9 \mathrm{~km}$ between the stations is short, and the station in Torun is located on the outskirts of the city. The comparative studies carried out showed that in the years 1996-2000 (then the observations of cloud cover in Koniczynka were carried out) the cloud cover in this station was higher by $4 \%$ compared to Torun (Uscka et al. 2001).

Based on a comparison of the diurnal values of individual components of the radiation balance with cloudiness, it was established that the values should be considered separately for each month. A subsequent analysis demonstrated that cloudiness influences $S \downarrow$ and $L \downarrow$ the most. In the case of $S \downarrow$, the Pearson linear correlation coefficient $(\mathrm{R})$ reached its highest values in summer (June and July, 0.84), and its lowest in winter (January, 0.69$)$. August $(R=0.68)$ was the only month to disturb the otherwise consistent pattern. The dependence of $\mathrm{S} \downarrow$ on cloudiness had a second-degree curvilinear relationship. As not only the degree of cloud cover but also the type of clouds was important. High-level clouds let a large amount of solar radiation pass, but in the case of partial cloudiness, formed by $\mathrm{Cu}$ and $\mathrm{Cb}$ types, additional reflection of solar rays from the clouds occurs, thus possibly increasing the amount of solar energy retained on the Earth's surface. In the winter season, solar radiation is additionally absorbed by fog, blizzards and increased amounts of aerosol amount of anthropogenic origin. The reflected solar radiation $(\mathrm{S} \uparrow)$ also shows a statistically significant correlation with the degree of cloudiness, but it is not due to the direct influence of clouds, because $\mathrm{S} \uparrow$ increases as $\mathrm{S} \downarrow$ rises.

The shortwave radiation balance $\left(\mathrm{S}^{*}\right)$ decreases as cloudiness increases (Fig. 8). This correlation is also a second- degree equation. The highest values of $\mathrm{S}^{*}$ were observed when the sky was clear or the amount of clouds was negligible. The $R$-value varied from 0.84 in June and July to 0.68 in August and 0.70 in December and January.

The downward atmospheric radiation $\mathrm{L} \downarrow$ is another component that is strongly correlated with cloudiness. Clouds, being made of water, are highly capable of absorbing longwave radiation and its further emission, including towards Earth's surface. Yet, our analysis of data brought the conclusion that only from November to March was the correlation significant (with the greatest value of $R$ in February, 0.82). In the other months, it was rather poor. A greater influence of cloudiness on $L \downarrow$ in the cold half of the year resulted from the structure of clouds, as massive low-level sheet clouds occur more frequently then (Wójcik and Uscka 1999).

Then again, the longwave radiation balance $\left(\mathrm{L}^{*}\right)$ demonstrates a substantial dependence on cloudiness in all months of the year, with the greatest value of the correlation coefficient, $R$, in winter (January and February, 0.91 ). Longwave radiation balance is lowest in overcast weather. The losses of energy from the surface are a few orders of magnitude smaller than under clear skies.

The conflicting tendencies of the influence of cloudiness on $\mathrm{S}^{*}$ and $\mathrm{L}^{*}$ result in the fact that $\mathrm{Q}^{*}$ shows a variable correlation with cloudiness. The modelled correlation of $\mathrm{K}$ $*, \mathrm{~L} *$ and $\mathrm{Q} *$ with changes in cloud cover in individual months of the year is presented in Fig. 9.

At smaller cloud amounts, a lot of $\mathrm{S} \downarrow$ reaches the Earth's surface and the balance of $\mathrm{S}^{*}$ is greater, while cloudless weather favours longwave radiation emittance and increases $L^{*}$, which considerably reduces Q*. Having analysed the correlations of $\mathrm{Q}^{*}$ and cloudiness, it was established that in four months-February, March, October and November - the radiation balance has very low values of $R$ ( 0.24 in February). In those months, $Q^{*}$ remained close to zero and even minor changes in $\mathrm{S}^{*}$ or $\mathrm{L}^{*}$ would disturb the relationship with cloudiness. In other months, the correlation is distinct: January 
Fig. 7 Mean daily course of radiation balance fluxes at Koniczynka in June, December and year, 2011-2018

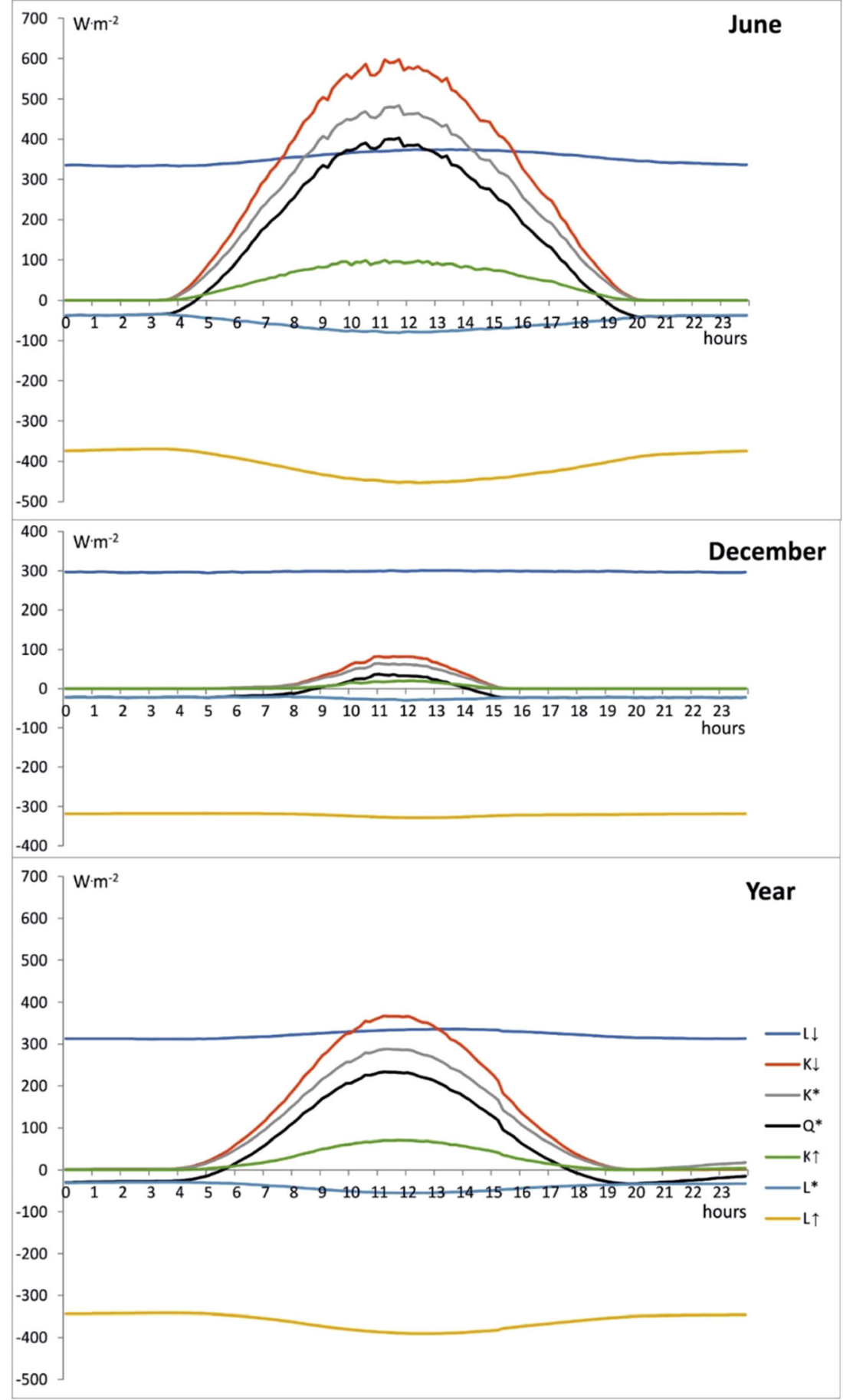

(0.82), December (0.83) and June (0.79). At low cloudiness, the amount of incoming solar radiation is greatest; hence, the high values of $Q^{*}$, whereas a great quantity of clouds restricts $\mathrm{Q}^{*}$, reduces $\mathrm{S} \downarrow$ and increases $\mathrm{L} \downarrow$.

The influence of cloudiness on the course of $\mathrm{Q}^{*}$ components is evident in the diurnal cycle. Figure 10 presents the course of Q* components on days with low cloudiness (18-19 June 2012) and high cloudiness (20-21 June 2012).

\subsection{The influence of atmospheric circulation on components of radiation balance}

Using the author's own set of synoptic situation types based on the criteria proposed by Niedźwiedź (1981) it was found that in the analysed period at Koniczynka a slight prevalence of anticyclonic patterns $(50.1 \%)$ was observed over cyclonic weather $(48.0 \%)$-Table 3 . With cyclonic circulation, 
Fig. 8 Correlation between $\mathrm{S}^{*}$, $\mathrm{L}^{*}$ and $\mathrm{Q}^{*}$ at Koniczynka and cloudiness at Torun in June (red dots) and December (blue dots) in the period 2011-2018

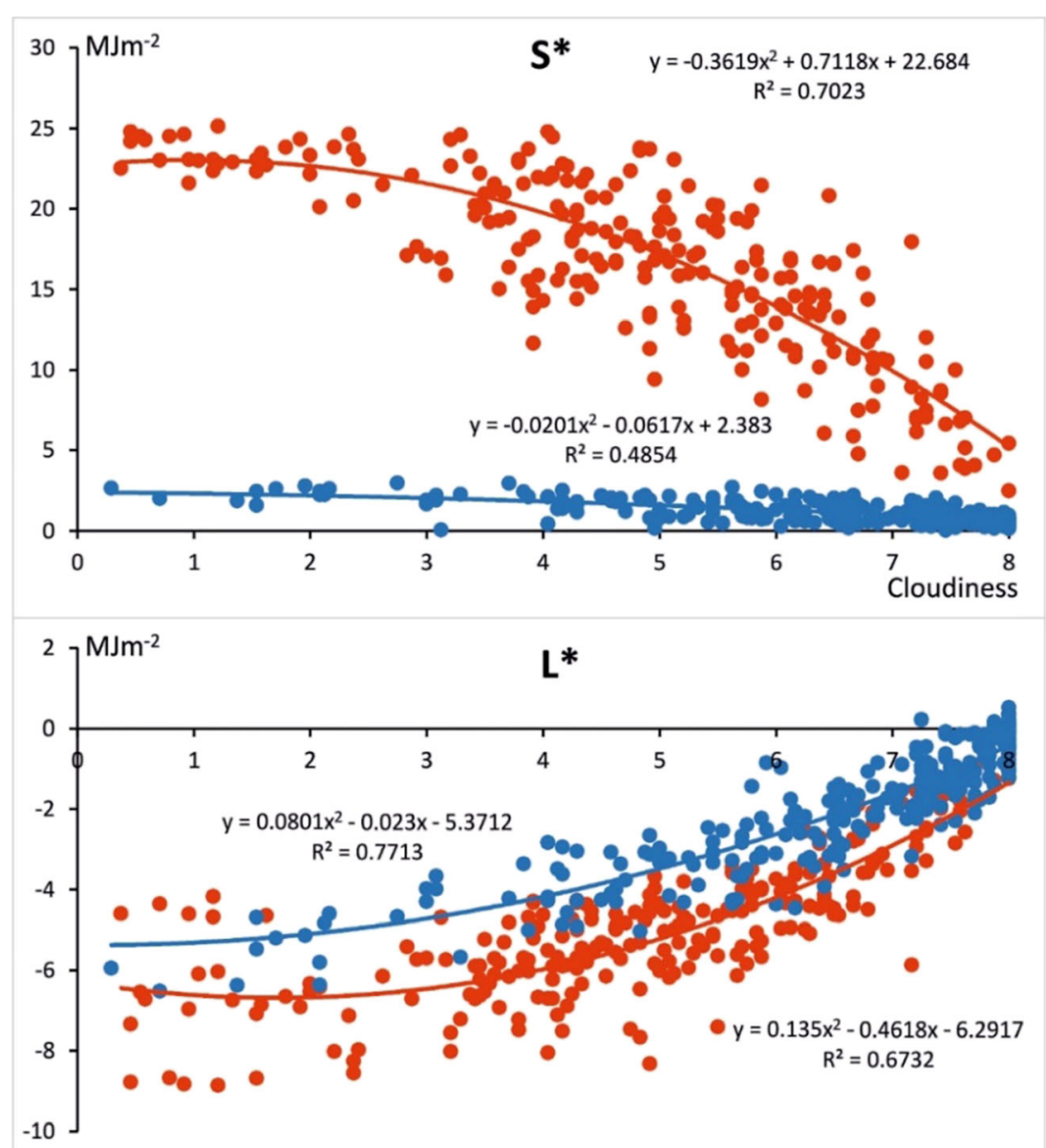

Cloudiness

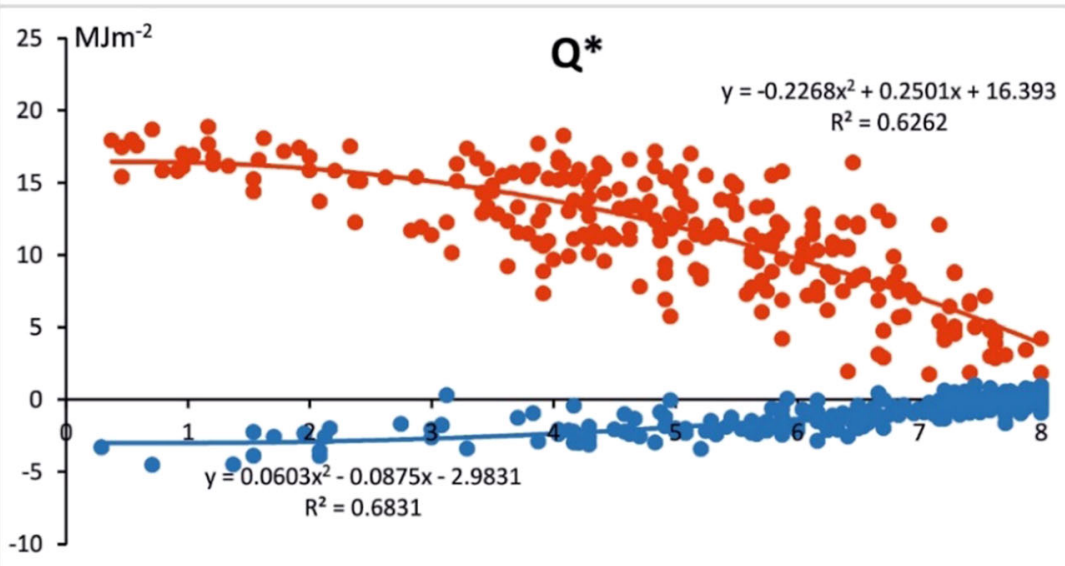

Cloudiness westerly advection was dominant: SWc (11.6\%), Wc (7.9\%) and NWc $(6.8 \%)$. On the other hand, for anticyclonic situations, the following advection types prevailed: SEa (8.6\%), NWa $(7.5 \%)$ and $\mathrm{Ka}(7.2 \%)$. In most seasons, anticyclonic patterns were the most frequent and only in winter were there more cyclonic situations $(55.4 \%)$ as a result of an increase in the frequency of westerly types (e.g. SWc 17.3\%). The structure of synoptic types in the analysed period was similar to their frequency in the years 1881-2005 in Torun (Przybylak and Maszewski 2009).

"Synoptic types" described in methodology

Different air masses and conditions of cloud formation are connected with the type of barometric centre (anticyclone or cyclone) and the direction of advection. Upon analysis, it was found that anticyclonic situations were accompanied by less cloudiness, with an annual average of 4.6 (on a scale of 0 to 8), 

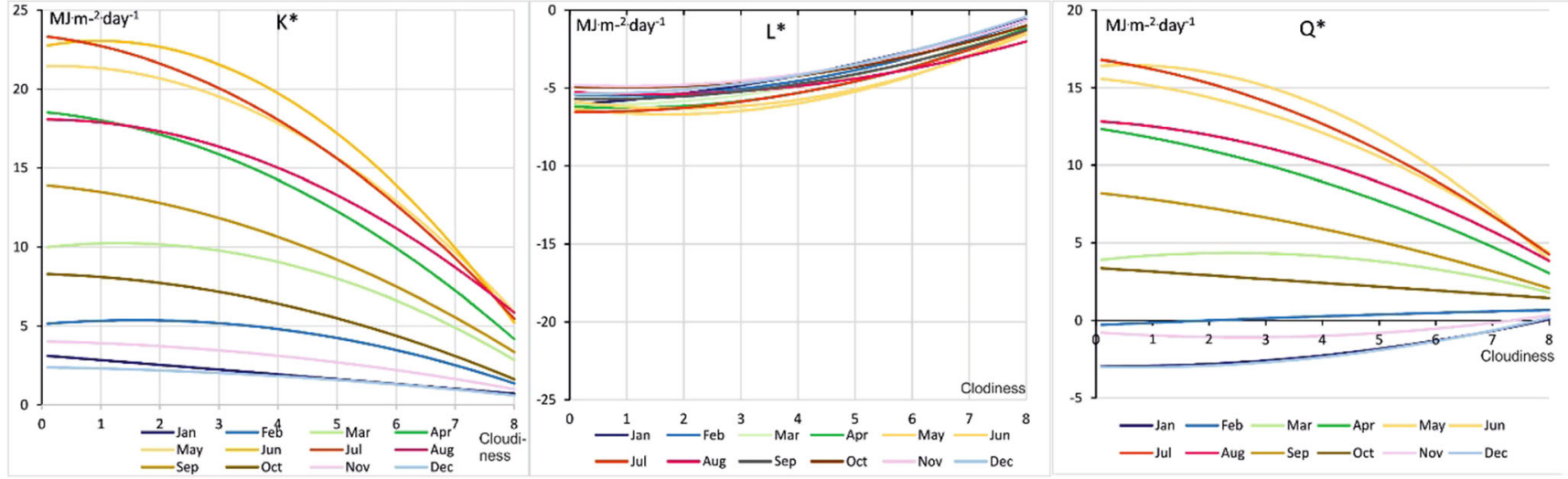

Fig. 9 Correlation of shortwave (S*), longwave (L*) and radiation balance ( $\left.\mathrm{Q}^{*}\right)$ with cloudiness at Koniczynka in 2011-2018

whereas with cyclonic patterns it was 5.9. A particularly low amount of cloud was observed for such anticyclonic patterns as $\mathrm{Ca}$ (3.6), $\mathrm{Na}$ and $\mathrm{Sa}$ (4.3), SEa (4.4) and $\mathrm{Ka}$ (4.5). Considerable cloudiness occurred with Ec (6.7), at the cyclone centre (Cc 6.4) and along the cyclonic trough Bc (6.3). The correlations were sustained in every season of the year.

The ascertained dependence of the components of $\mathrm{Q}^{*}$ on cloudiness makes them also dependent on the synoptic situation types. Combined circulation types were used and the results were presented for a year and its calendar seasons (Table 4) and for specific months (Fig. 11).

\subsubsection{Year}

The weather conditions that occur with anticyclonic situations favour a greater income of solar radiation $\left(\mathrm{S} \downarrow=12.13 \mathrm{MJ} \cdot \mathrm{m}^{-2}\right.$. day $^{-1}$ ) than happens with cyclonic patterns characterised by increased cloud cover $\left(8.82 \mathrm{MJ} \cdot \mathrm{m}^{-2} \cdot \mathrm{day}^{-1}\right)$. On the one hand, there was more reflected solar radiation (in absolute values), but still $\mathrm{S}^{*}$ was more favourable in anticyclonic situations $\left(9.80 \mathrm{MJ} \cdot \mathrm{m}^{-2} \cdot\right.$ day $^{-1}$ and $7.15 \mathrm{MJ} \cdot \mathrm{m}^{-2} \cdot$ day $^{-1}$, respectively). The longwave radiation balance was less favourable when anticyclonic types prevailed $\left(\mathrm{L}^{*}=-4.04 \mathrm{MJ} \cdot \mathrm{m}^{-2} \cdot \mathrm{day}^{-1}\right)$ than in cyclonic situations $\left(-3.10 \mathrm{MJ} \cdot \mathrm{m}^{-2} \cdot \mathrm{day}^{-1}\right)$. However, the general balance $\mathrm{Q}^{*}$ was better in anticyclonic situations $\left(5.76 \mathrm{MJ} \cdot \mathrm{m}^{-2} \cdot \mathrm{day}^{-1}\right)$ than for the cyclonic types $(4.05 \mathrm{MJ}$. $\mathrm{m}^{-2} \cdot$ day $^{-1}$ ). The decisive element is the increased amount of incoming solar radiation. Of all the synoptic types, the highest value of $Q^{*}$ was obtained for $\mathrm{Ca}+\mathrm{Ka}\left(6.77 \mathrm{MJ} \cdot \mathrm{m}^{-2} \cdot\right.$ day $\left.^{-1}\right)$ and $\mathrm{N}+\mathrm{NEa}\left(6.66 \mathrm{MJ} \cdot \mathrm{m}^{-2} \cdot \mathrm{day}^{-1}\right)$ when cloudiness was the lowest. The lowest $\mathrm{Q}^{*}$ occurred for S+SWc $\left(3.46 \mathrm{MJ} \cdot \mathrm{m}^{-2} \cdot\right.$ day $\left.^{-1}\right)$, $\mathrm{Cc}+\mathrm{Bc}$ and $\mathrm{W}+\mathrm{NWc}\left(3.82 \mathrm{MJ} \cdot \mathrm{m}^{-2} \cdot \mathrm{day}^{-1}\right)$. These are types whose advection is westerly and which bring humid air masses of maritime origin and, consequently, large cloud amounts.

\subsubsection{Winter}

In winter, little solar energy reaches the Earth's surface and the radiation balance is negative. Greater amounts of incoming

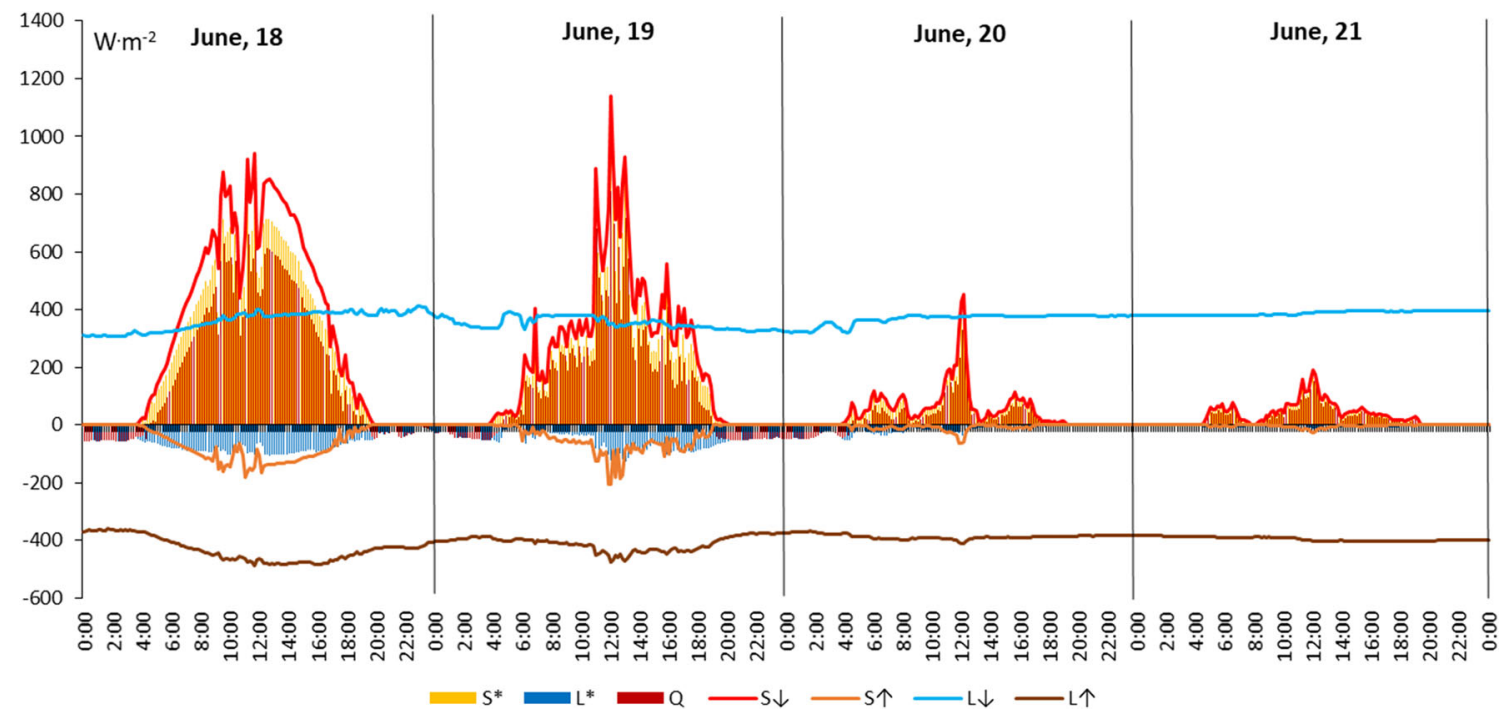

Fig. 10 Course of radiation balance components at Koniczynka on June 18-21, 2012 
Table 3 Frequency (\%) of synoptic types and mean values of cloudiness $(\mathrm{C}$, in $0-8$ scale) at Koniczynka according to seasons in the years 2011-2018

\begin{tabular}{|c|c|c|c|c|c|c|c|c|c|c|}
\hline \multirow[t]{2}{*}{ Synoptic types } & \multicolumn{2}{|l|}{ DJF } & \multicolumn{2}{|c|}{ MAM } & \multicolumn{2}{|l|}{ JJA } & \multicolumn{2}{|l|}{ SON } & \multicolumn{2}{|l|}{ Year } \\
\hline & $\%$ & $\mathrm{C}$ & $\%$ & $\mathrm{C}$ & $\%$ & $\mathrm{C}$ & $\%$ & $\mathrm{C}$ & $\%$ & $\mathrm{C}$ \\
\hline $\mathrm{Ca}$ & 2.1 & 5.2 & 5.7 & 3.3 & 5.2 & 3.0 & 4.0 & 4.0 & 4.2 & 3.6 \\
\hline $\mathrm{Ka}$ & 5.4 & 5.3 & 8.0 & 3.8 & 9.1 & 4.2 & 6.2 & 5.2 & 7.2 & 4.5 \\
\hline $\mathrm{Na}$ & 1.4 & 5.8 & 2.7 & 3.8 & 1.6 & 4.2 & 0.8 & 3.7 & 1.6 & 4.3 \\
\hline $\mathrm{NEa}$ & 2.9 & 5.4 & 7.5 & 4.4 & 5.0 & 4.1 & 4.0 & 4.9 & 4.9 & 4.6 \\
\hline $\mathrm{Ea}$ & 3.9 & 5.6 & 3.9 & 3.7 & 2.0 & 4.4 & 3.2 & 4.7 & 3.3 & 4.6 \\
\hline SEa & 9.4 & 5.2 & 6.3 & 3.9 & 6.1 & 3.5 & 12.6 & 4.4 & 8.6 & 4.4 \\
\hline $\mathrm{Sa}$ & 3.6 & 5.5 & 2.3 & 3.6 & 2.2 & 3.3 & 4.9 & 4.2 & 3.3 & 4.3 \\
\hline SWa & 6.9 & 6.1 & 4.1 & 4.1 & 7.6 & 4.4 & 7.1 & 5.5 & 6.4 & 5.1 \\
\hline Wa & 2.1 & 6.5 & 2.3 & 4.4 & 4.1 & 4.7 & 4.0 & 5.1 & 3.1 & 5.1 \\
\hline NWa & 6.2 & 6.3 & 8.7 & 4.5 & 10.3 & 4.5 & 4.7 & 4.8 & 7.5 & 4.9 \\
\hline $\mathrm{Cc}$ & 2.6 & 6.8 & 2.9 & 6.6 & 3.3 & 6.0 & 1.4 & 6.0 & 2.5 & 6.4 \\
\hline $\mathrm{Bc}$ & 4.4 & 7.0 & 4.2 & 6.4 & 4.5 & 5.4 & 5.9 & 6.3 & 4.8 & 6.3 \\
\hline $\mathrm{Nc}$ & 0.7 & 6.7 & 1.1 & 5.7 & 2.3 & 5.1 & 1.4 & 5.5 & 1.4 & 5.5 \\
\hline $\mathrm{NEc}$ & 1.7 & 7.0 & 3.5 & 5.5 & 3.3 & 5.4 & 2.1 & 7.0 & 2.6 & 6.0 \\
\hline $\mathrm{Ec}$ & 0.8 & 7.6 & 1.9 & 6.3 & 0.1 & 5.7 & 0.3 & 7.1 & 0.8 & 6.7 \\
\hline SEc & 4.6 & 6.7 & 7.1 & 4.9 & 5.4 & 5.1 & 6.2 & 6.2 & 5.8 & 5.6 \\
\hline $\mathrm{Sc}$ & 5.1 & 6.7 & 3.5 & 5.3 & 2.9 & 5.4 & 3.2 & 6.3 & 3.7 & 6.0 \\
\hline SWc & 17.3 & 6.3 & 9.4 & 5.7 & 9.2 & 5.1 & 10.7 & 5.8 & 11.6 & 5.8 \\
\hline Wc & 10.7 & 6.7 & 5.4 & 5.3 & 7.1 & 5.3 & 8.7 & 6.0 & 7.9 & 5.9 \\
\hline NWc & 7.5 & 6.6 & 7.3 & 5.2 & 6.1 & 5.4 & 6.5 & 6.0 & 6.8 & 5.8 \\
\hline $\mathrm{X}$ & 0.7 & 5.9 & 2.2 & 5.5 & 2.6 & 4.7 & 2.3 & 5.7 & 2.0 & 5.3 \\
\hline Anticyclonic & 43.9 & 5.6 & 51.5 & 4.0 & 53.3 & 4.1 & 51.5 & 4.7 & 50.1 & 4.6 \\
\hline Cyclonic & 55.4 & 6.6 & 46.3 & 5.6 & 44.2 & 5.3 & 46.2 & 6.1 & 48.0 & 5.9 \\
\hline
\end{tabular}

Table 4 Mean values of radiation balance components (in $\mathrm{MJm}^{-2}$ day $^{-1}$ ) at Koniczynka according to synoptic situations types in the years 2011-2018

\begin{tabular}{lllllllll}
\hline Synoptic types & Days & $\mathrm{S} \downarrow$ & $\mathrm{S} \uparrow$ & $\mathrm{L} \downarrow$ & $\mathrm{L} \uparrow$ & $\mathrm{S} *$ & $\mathrm{~L}^{*}$ & $\mathrm{Q}^{*}$ \\
\hline $\mathrm{N}+\mathrm{NEa}$ & 190 & 13.73 & 2.70 & 27.10 & 31.48 & 11.03 & -4.38 & 6.66 \\
E+Sea & 346 & 10.97 & 2.22 & 26.81 & 30.75 & 8.75 & -3.94 & 4.81 \\
S+Swa & 283 & 10.38 & 1.89 & 27.64 & 31.33 & 8.49 & -3.69 & 4.79 \\
$\mathrm{~W}+\mathrm{NWa}$ & 310 & 12.26 & 2.23 & 27.79 & 31.75 & 10.03 & -3.95 & 6.06 \\
$\mathrm{Ca}+\mathrm{Ka}$ & 334 & 13.78 & 2.69 & 27.08 & 31.41 & 11.09 & -4.33 & 6.77 \\
$\mathrm{~N}+\mathrm{NEc}$ & 117 & 11.43 & 2.39 & 28.13 & 31.52 & 9.03 & -3.39 & 5.65 \\
E+Sec & 193 & 10.54 & 2.04 & 28.22 & 31.54 & 8.49 & -3.32 & 5.17 \\
S+SWc & 447 & 8.10 & 1.51 & 27.54 & 30.67 & 6.59 & -3.12 & 3.46 \\
W+NWc & 432 & 8.55 & 1.59 & 27.71 & 30.84 & 6.96 & -3.14 & 3.82 \\
Cc+Bc & 213 & 7.87 & 1.45 & 28.69 & 31.30 & 6.43 & -2.61 & 3.82 \\
X & 57 & 12.85 & 2.11 & 29.53 & 33.17 & 10.74 & -3.64 & 7.10 \\
Anticyclonic & 1463 & 12.13 & 2.33 & 27.28 & 31.32 & 9.80 & -4.04 & 5.76 \\
Cyclonic & 1402 & 8.82 & 1.67 & 27.91 & 31.01 & 7.15 & -3.10 & 4.05 \\
\hline
\end{tabular}

shortwave radiation $\mathrm{S} \downarrow$ were observed in anticyclonic situations (on average $3.1 \mathrm{MJ} \cdot \mathrm{m}^{-2} \cdot$ day $^{-1}$ ) than in cyclonic ones $\left(2.3 \mathrm{MJ} \cdot \mathrm{m}^{-2} \cdot\right.$ day $\left.^{-1}\right)$. Of the combined types, the greatest $\mathrm{S} \uparrow$ occurred with $\mathrm{N}+\mathrm{NEa}\left(4.3 \mathrm{MJ} \cdot \mathrm{m}^{-2} \cdot\right.$ day $\left.^{-1}\right)$ with incoming continental Arctic or Polar air masses characterised by modest cloudiness. On the other hand, little $\mathrm{S} \uparrow$ was observed with $\mathrm{Cc}+\mathrm{Bc}\left(2.0 \mathrm{MJ} \cdot \mathrm{m}^{-2} \cdot \mathrm{day}^{-1}\right)$ and $\mathrm{W}+\mathrm{NWc}\left(2.1 \mathrm{MJ} \cdot \mathrm{m}^{-2}\right.$. day $^{-1}$ ). Radiation balance was negative for most of the combined circulation types (the greatest losses occurred with $\mathrm{Ca}+$ $\mathrm{Ka}:-0.8 \mathrm{MJ} \cdot \mathrm{m}^{-2} \cdot$ day $^{-1}$ ) with the exception of E+Sec, where the value of $\mathrm{Q}^{*}$ was zero.

\subsubsection{Spring}

In spring, the solar angle increases and the day grows longer, so the amount of incoming solar energy is greater than its losses. In anticyclonic situations the average diurnal amount of $\mathrm{S} \downarrow$ was $16.1 \mathrm{MJ} \cdot \mathrm{m}^{-2} \cdot$ day $^{-1}$, and in cyclonic situations, it was $12.7 \mathrm{MJ} \cdot \mathrm{m}^{-2} \cdot$ day $^{-1}$. The greatest amount of incoming shortwave radiation was common with E+SEa (18.0 MJ. $\mathrm{m}^{-2} \cdot$ day $\left.^{-1}\right), \mathrm{S}+\mathrm{SWa}\left(16.6 \mathrm{MJ} \cdot \mathrm{m}^{-2} \cdot\right.$ day $\left.^{-1}\right)$ and $\mathrm{Ca}+\mathrm{Ka}(16.3$ $\mathrm{MJ} \cdot \mathrm{m}^{-2} \cdot$ day $\left.^{-1}\right)$, whereas it was the lowest with $\mathrm{CC}+\mathrm{Bc}(8.9$ $\mathrm{MJ} \cdot \mathrm{m}^{-2} \cdot$ day $\left.^{-1}\right)$ and $\mathrm{W}+\mathrm{NWc}\left(13.0 \mathrm{MJ} \cdot \mathrm{m}^{-2} \cdot\right.$ day $\left.^{-1}\right)$. A high influx of $\mathrm{S} \downarrow$ results in a considerable warming of the ground and a subsequent emittance of $\mathrm{L} \uparrow$; for example, for $\mathrm{E}+\mathrm{SEa}$ $\left(32.4 \mathrm{MJ} \cdot \mathrm{m}^{-2} \cdot\right.$ day $\left.^{-1}\right)$. With a great amount of cloud, typical of $\mathrm{Cc}+\mathrm{Bc}$, a large portion of solar energy comes back to the surface $(\mathrm{L} \downarrow)\left(28.3 \mathrm{MJ} \cdot \mathrm{m}^{-2} \cdot\right.$ day $\left.^{-1}\right)$. The presence of clouds markedly influenced $\mathrm{L}^{*}$ by affecting $\mathrm{L} \downarrow$ which amounted to $61 \%$ of $\mathrm{L} \uparrow$ with $\mathrm{N}+\mathrm{NEa}$, but as much as $92 \%$ of $\mathrm{L} \uparrow$ with $\mathrm{Cc}+$ Bc. Higher values of $\mathrm{Q}^{*}$ were observed with anticyclonic types $\left(9.0 \mathrm{MJ} \cdot \mathrm{m}^{-2} \cdot\right.$ day $\left.^{-1}\right)$ rather than cyclonic $\left(6.5 \mathrm{MJ} \cdot \mathrm{m}^{-2}\right.$. day $\left.{ }^{-1}\right)$. The greatest energy income occurred with E+SEa (9.2 $\mathrm{MJ} \cdot \mathrm{m}^{-2} \cdot$ day $\left.^{-1}\right)$, and the smallest with $\mathrm{Cc}+\mathrm{Bc}\left(4.7 \mathrm{MJ} \cdot \mathrm{m}^{-2}\right.$. day $\left.^{-1}\right)$.

\subsubsection{Summer}

In summer, the solar radiation influx is greatest, but is accompanied by the greatest losses from heated ground. With anticyclonic types $\mathrm{S} \downarrow$ averaged $19.9 \mathrm{MJ} \cdot \mathrm{m}^{-2} \cdot$ day $^{-1}$. A great influx of $\mathrm{S} \downarrow$ was observed with $\mathrm{Ca}+\mathrm{Ka}\left(21.1 \mathrm{MJ} \cdot \mathrm{m}^{-2} \cdot\right.$ day $\left.^{-1}\right)$ and $\mathrm{N}+$ $\mathrm{NEa}\left(20.4 \mathrm{MJ} \cdot \mathrm{m}^{-2} \cdot \mathrm{day}^{-1}\right)$. On the other hand, with cyclonic types the energy income averaged $16.5 \mathrm{MJ} \cdot \mathrm{m}^{-2} \cdot$ day $^{-1}$. As in the case of the other seasons, $\mathrm{Cc}+\mathrm{Bc}$ saw the lowest $\mathrm{S} \downarrow$ (14.5 $\mathrm{MJ} \cdot \mathrm{m}^{-2} \cdot$ day $\left.^{-1}\right)$. The balance of $\mathrm{S}^{*}$ ranged from $12.2 \mathrm{MJ} \cdot \mathrm{m}^{-2}$. day $^{-1}(\mathrm{Cc}+\mathrm{Bc})$ to $17.6 \mathrm{MJ} \cdot \mathrm{m}^{-2} \cdot \mathrm{day}^{-1}(\mathrm{Ca}+\mathrm{Ka})$. The emittance of energy ( $\mathrm{L} \uparrow$ ) from the surface ranged from $34.7 \mathrm{MJ} \cdot \mathrm{m}^{-2}$. day $^{-1}(\mathrm{~W}+\mathrm{NWc})$ to $37.0 \mathrm{MJ} \cdot \mathrm{m}^{-2} \cdot$ day $^{-1}(\mathrm{E}+\mathrm{SEa})$, whereas the quantity of energy returned $(\mathrm{L} \downarrow)$ with the types amounted to $\left(31.6\right.$ and $30.9 \mathrm{MJ} \cdot \mathrm{m}^{-2} \cdot$ day $^{-1}$, respectively). The balance of $\mathrm{L}^{*}$ ranged from $-3.7 \mathrm{MJ} \cdot \mathrm{m}^{-2} \cdot \mathrm{day}^{-1}(\mathrm{Cc}+\mathrm{Bc})$ to $-5.2 \mathrm{MJ} \cdot \mathrm{m}^{-2}$. 


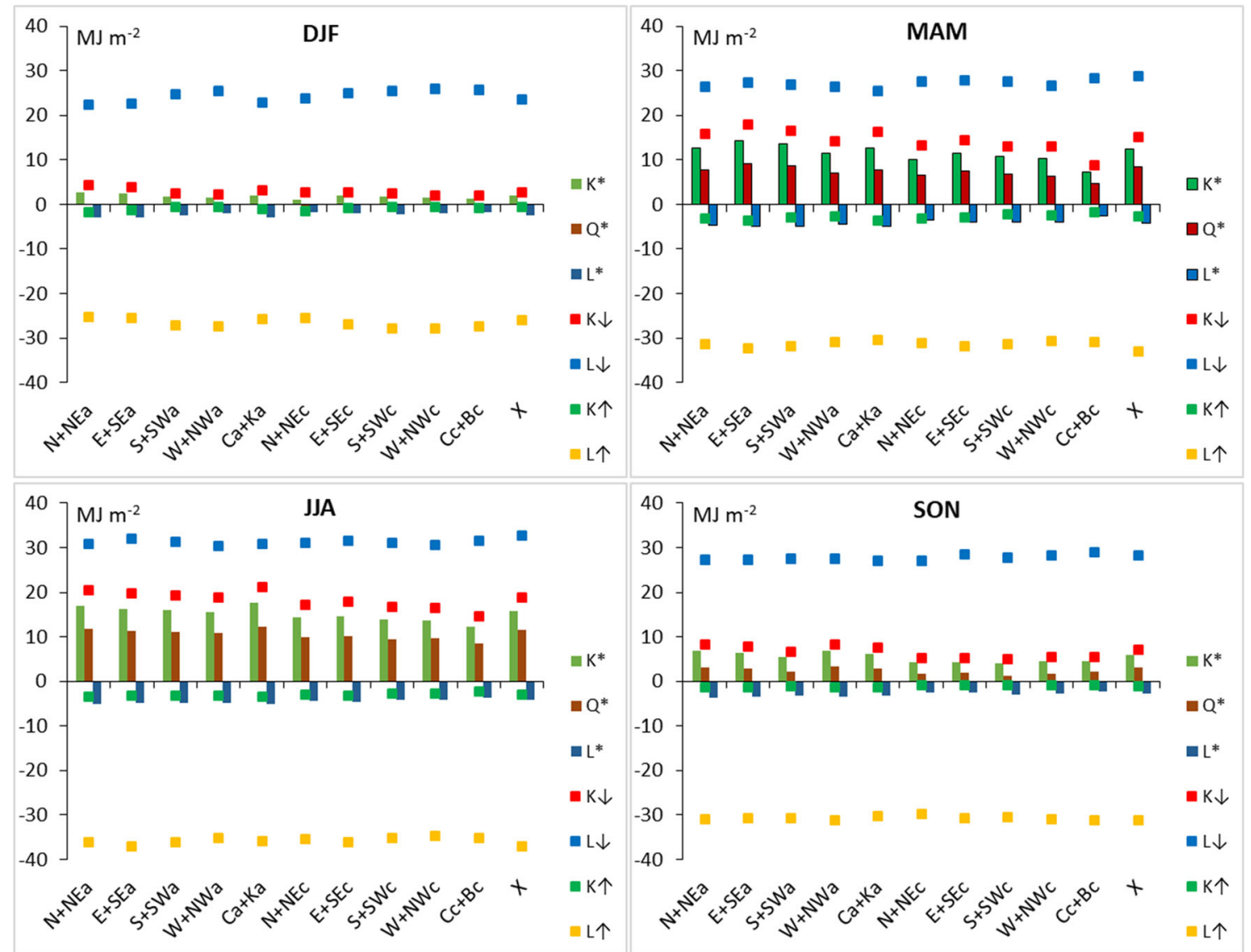

Fig. 11 Daily mean sum of radiation balance components at Koniczynka for individual types of synoptic situations for the seasons in 2011-2018

day $^{-1}(\mathrm{Ca}+\mathrm{Ka})$. For the same types, $\mathrm{Q}^{*}$ reached $8.5 \mathrm{MJ} \cdot \mathrm{m}^{-2}$. day $^{-1}$ and $12.4 \mathrm{MJ} \cdot \mathrm{m}^{-2} \cdot$ day $^{-1}$, respectively.

\subsubsection{Autumn}

Solar energy income falls in autumn. The greatest $\mathrm{S} \downarrow$ was recorded for $\mathrm{W}+\mathrm{NWa}\left(8.4 \mathrm{MJ} \cdot \mathrm{m}^{-2} \cdot \mathrm{day}^{-1}\right)$ and $\mathrm{N}+\mathrm{NEa}(8.2$ $\left.\mathrm{MJ} \cdot \mathrm{m}^{-2} \cdot \mathrm{day}^{-1}\right)$, and the smallest for S+SWc $\left(4.9 \mathrm{MJ} \cdot \mathrm{m}^{-2}\right.$. day $^{-1}$ ). The amount of $\mathrm{L} \uparrow$ also dropped: to $30.8 \mathrm{MJ} \cdot \mathrm{m}^{-2}$. day $^{-1}$ for both cyclonic and anticyclonic weather types. However, the balance of $\mathrm{L}^{*}$ was less favourable with anticyclonic types $\left(-2.7 \mathrm{MJ} \cdot \mathrm{m}^{-2} \cdot\right.$ day $^{-1}$ vs. $-3.4 \mathrm{MJ} \cdot \mathrm{m}^{-2} \cdot$ day $\left.^{-1}\right)$. The radiation balance ranged between $1.2 \mathrm{MJ} \cdot \mathrm{m}^{-2} \cdot \mathrm{day}^{-1}$ for $\mathrm{S}+$ $\mathrm{SWc}$ and $3.3 \mathrm{MJ} \cdot \mathrm{m}^{-2} \cdot \mathrm{day}^{-1}$ for $\mathrm{W}+\mathrm{NWa}$.

\subsection{Year-on-year variability of radiation balance components}

The eight-year-long registration of radiation balance component data at Koniczynka does not allow for an evaluation of the trend, but an attempt can be made to find out the reasons for their variability.

The annual income of $\mathrm{S} \downarrow$ at Koniczynka averaged at $3,866.3 \mathrm{MJ} \cdot \mathrm{m}^{-2}$ (Table 5). However, there were quite substantial differences between individual years, from $3,488.0 \mathrm{MJ} \cdot \mathrm{m}^{-2}$ in 2017 , when cloudiness was very high (5.7) and there was a lot of precipitation $-727.2 \mathrm{~mm}$ (Table 1), to $4,025.5 \mathrm{MJ} \cdot \mathrm{m}^{-2}$ in 2018 with the degree of cloudiness reaching only 4.8 . That had been the sunniest year since 1994 - the year measurements started at Koniczynka (UsckaKowalkowska et al. 2015), and the sunshine duration reached 2,134.2 hours (Table 1). On the other hand, $\mathrm{S} \uparrow$ exhibited different correlations. At an average value of reflected radiation of $737.1 \mathrm{MJ} \cdot \mathrm{m}^{-2}$, losses were greatest in $2013(940.3 \mathrm{MJ}$. $\mathrm{m}^{-2}$ ), when the winter was snowy, and smallest in the cloudy year $2017\left(551.2 \mathrm{MJ} \cdot \mathrm{m}^{-2}\right)$.

The fluxes of longwave radiation are much greater. The ground surface at Koniczynka emitted on average 11,421.5 $\mathrm{MJ} \cdot \mathrm{m}^{-2}$; however, the differences between individual years are small: from $11,138.1 \mathrm{MJ} \cdot \mathrm{m}^{-2}$ in 2014 to $11,657.4 \mathrm{MJ}$. $\mathrm{m}^{-2}$ in 2018. The latter was the warmest year in recent years (Table 2). The downward atmospheric radiation $(\mathrm{L} \downarrow)$ increased from $9,790.5 \mathrm{MJ} \cdot \mathrm{m}^{-2}$ in 2014 to $10,300.3 \mathrm{MJ} \cdot \mathrm{m}^{-2}$ in the cloudy 2017, with an average value of $10,110.8 \mathrm{MJ} \cdot \mathrm{m}^{-2}$.

Quite substantial differences were found in the balance $\mathrm{Q}^{*}$, which was lowest in $2011\left(1,640.4 \mathrm{MJ} \cdot \mathrm{m}^{-2}\right)$ and highest in $2018\left(2,081.6 \mathrm{MJ} \cdot \mathrm{m}^{-2}\right)$-Table 5. The low values of $\mathrm{Q}^{*}$ in 2011 were connected with a reduced $\mathrm{S} *\left(3,039.1 \mathrm{MJ} \cdot \mathrm{m}^{-2}\right)$ 
Table 5 Mean yearly values of radiation balance components at Koniczynka in the years 2011-2018

\begin{tabular}{lllllllll}
\hline Year & $\mathrm{S} \downarrow$ max $\left[\mathrm{W} \cdot \mathrm{m}^{-2}\right]$ & $\mathrm{S} \downarrow\left[\mathrm{MJm}^{-2}\right]$ & $\mathrm{S} \uparrow\left[\mathrm{MJ}^{-2}\right]$ & $\mathrm{L} \uparrow\left[\mathrm{MJ}^{-2}\right]$ & $\mathrm{L} \downarrow\left[\mathrm{MJ}^{-2}\right]$ & $\mathrm{S}^{*}\left[\mathrm{MJm}^{-2}\right]$ & $\mathrm{L}^{*}\left[\mathrm{MJ} \cdot \mathrm{m}^{-2}\right]$ & $\mathrm{Q} *\left[\mathrm{MJ} \cdot \mathrm{m}^{-2}\right]$ \\
\hline 2011 & 1075.2 & 3901.1 & 861.8 & 11431.5 & 10032.8 & 3039.1 & -1398.7 & 1640.4 \\
2012 & 1139.2 & 3840.1 & 751.9 & 11405.8 & 10050.4 & 3088.2 & -1355.4 & 1732.8 \\
2013 & 995.1 & 3845.5 & 940.3 & 11299.1 & 10125.3 & 2905.2 & -1173.9 & 1731.4 \\
2014 & 1137.5 & 3968.1 & 760.7 & 11138.1 & 9790.5 & 3207.3 & -1341.0 & 1866.4 \\
2015 & 1100.7 & 3957.9 & 737.9 & 11512.2 & 10073.1 & 3220.0 & -1439.1 & 1780.9 \\
2016 & 1058.1 & 3885.6 & 690.4 & 11485.7 & 10214.0 & 3195.2 & -1271.8 & 1923.5 \\
2017 & 1030.4 & 3488.0 & 551.2 & 11448.7 & 10300.3 & 2943.5 & -1148.4 & 1795.0 \\
2018 & 1075.9 & 4035.5 & 599.4 & 11657.4 & 10300.1 & 3439.0 & -1357.4 & 2081.6 \\
$2011-2018$ & 1139.2 & 3866.3 & 737.1 & 11421.5 & 10110.8 & 3129.2 & -1310.7 & 1818.5 \\
\hline
\end{tabular}

and major losses in the longwave radiation balance ( $\mathrm{L}^{*}$ $-1,398.7 \mathrm{MJ} \cdot \mathrm{m}^{-2}$ ). As regards 2018 , the year saw the greatest energy income $\left(\mathrm{S}^{*} 3,439.0 \mathrm{MJ} \cdot \mathrm{m}^{-2}\right)$ and $\mathrm{L}^{*}$ was $-1,357.4 \mathrm{MJ} \cdot \mathrm{m}^{-2}$. The exceptionally cloudy year $2017 \mathrm{had}$ a small income of $\mathrm{S}^{*}\left(2,943.5 \mathrm{MJ} \cdot \mathrm{m}^{-2}\right)$ but also the smallest losses of $\mathrm{L}^{*}\left(-1,148.4 \mathrm{MJ} \cdot \mathrm{m}^{-2}\right)$, which resulted in the energy balance of $1795,0 \mathrm{MJ} \cdot \mathrm{m}^{-2}$. Thus, it becomes evident how important cloudiness and the properties of incoming air masses are for the development of Q*.

\section{Summary and discussion}

The results obtained at Koniczynka in the years 2011-2018 made it possible to analyse the variability of the components of Q* in the diurnal and annual course. Furthermore, the components of $Q^{*}$ were found to depend considerably on atmospheric circulation, and on cloudiness in particular.

The values of $S \downarrow$ at Koniczynka are higher than the mean values calculated for the nearby cities of Torun and Bydgoszcz in 1956-1975 (Miara et al. 1987). The mean annual sum of $\mathrm{S} \downarrow$ at Koniczynka was $3,865.7 \mathrm{MJ} \cdot \mathrm{m}^{-2}$, whereas in Toruń it was 3,689.3 MJ.m ${ }^{-2}$ and in Bydgoszcz 3,649.2 $\mathrm{MJ} \cdot \mathrm{m}^{-2}$. The studies of Wójcik (1996), which covered the years 1983-1991, also revealed lower values of $\mathrm{S} \downarrow$ in Torun $\left(3,823.6 \mathrm{MJ} \cdot \mathrm{m}^{-2}\right)$. These are data from the years when in Poland and Europe there was a downward trend in the amount of solar radiation reaching the surface of the earth, which was related to the increasing dustiness of the atmosphere, known as "global dimming". In the 1980s, the trend reversed and the "global brightening" began (Wild 2009). From 1981 to 2015, the $\mathrm{S} \downarrow$ trend was 1.9-2.4 $\mathrm{Wm}^{-2}$ (Pfeifroth et al. 2018). This is consistent with the results of other studies which indicate that urban areas receive less downward shortwave solar radiation due to greater atmospheric pollution. As demonstrated in research carried out in Torun in 2012, the annual sum of $\mathrm{S} \downarrow$ there was approx. 30\% lower than at Koniczynka (Kejna et al. 2014a, b). Moreover, in the city of Łódź, the amount of solar radiation reaching the city was 5\% to $15 \%$ smaller compared with suburban areas (Podstawczyńska 2007).

As far as $\mathbf{S} \uparrow$ is concerned, its value at Koniczynka in analysed period $\left(736.6 \mathrm{MJ} \cdot \mathrm{m}^{-2}\right)$ was smaller than in Torun or Bydgoszcz in the second half of the 20th century. The reason could be a smaller albedo at Koniczynka, especially in winter, considering that snow cover has recently been less and less common in Poland (Szwed et al. 2017). The balance $\mathrm{S}^{*}$ at Koniczynka was $3,129.2 \mathrm{MJ} \cdot \mathrm{m}^{-2}$, and its values were more than $200 \mathrm{MJ} \cdot \mathrm{m}^{-2}$ higher than the corresponding values determined for 1956-1975 in the nearby cities. It was a lower value compared to the data from Wrocław-Swojec (grass surface) in 2007-2019, which is located further south (3155.0 $\mathrm{MJ} \cdot \mathrm{m}^{-2}$ ) - Bryś et al. (2020). The longwave radiation balance $\left(\mathrm{L}^{*}\right)$ at Koniczynka was lower than in Bydgoszcz and amounted to $1,310.7 \mathrm{MJ} \cdot \mathrm{m}^{-2}$. However, the result was comparable to the recent data from Wrockaw $\left(1313.8 \mathrm{MJ} \cdot \mathrm{m}^{-2}\right)$ Bryś et al. (2020). The differences were particularly clear in the cold half of the year. However, one should note that downward longwave radiation is higher in cities and, for example, in Łódź, the intensity of $\mathrm{L} \downarrow$ was $20-30 \mathrm{Wm}^{-2}$ higher, and also $\mathrm{L}^{*}$ was $10-40 \mathrm{Wm}^{-2}$ higher (Fortuniak et al. 2015). The radiation balance $\mathrm{Q}^{*}$ proved to be much more favourable at Koniczynka $\left(1,818.5 \mathrm{MJ} \cdot \mathrm{m}^{2}\right)$ than in Bydgoszcz $(1,356.2$ $\left.\mathrm{MJ} \cdot \mathrm{m}^{2}\right)$. Negative values of $\mathrm{Q}^{*}$ at Koniczynka were observed only in December and January. Similary in Wrocław (Bryś et al. 2020), while in Bydgoszcz they also occurred in February. Still, the values of Q* obtained at Koniczynka were lower than those from the Ojców National Park, where Q* amounted to $2,102 \mathrm{MJ} \cdot \mathrm{m}^{-2}$ in 2008 and even $2,231 \mathrm{MJ} \cdot \mathrm{m}^{-2}$ in 2009. Lower values were also found in Wrocław-in the period 2007-2019 (1,841.2 MJ.m $\left.{ }^{-2}\right)$ — Bryś et al. (2020). The obtained values are similar to the results of the conducted research, for example, in Germany in a similar climate zone (Power 2003).

The diurnal course of the components of $Q^{*}$ was asymmetrical with regard to noon, in particular in the course of $\mathrm{S} \downarrow$ (the effect of larger convective cloudiness in the afternoon and in 
$\mathrm{L} \uparrow$, which depends on the ground temperature). The obtained results are consistent with the studies for Cracow and GaikBrzezowa (Bokwa and Matuszyk 2007), Wrocław-Swojec (Bryś 2009; Bryś et al. 2020), Felin near Lublin (Kossowski and Łykowski 2007), or the Upper Silesia and the KrakówCzęstochowa Upland (Caputa and Wojkowski 2009).

Cloudiness has a great impact on $\mathrm{Q}^{*}$, and in particular on its components: $\mathrm{S} \downarrow$ and $\mathrm{L} \downarrow$. In the condition of overcast sky, the intensity of $S \downarrow$ is largely reduced as compared with the same when the sky is clear. At Koniczynka, this correlation had a second-degree curvilinear relationship and in the case of $\mathrm{S} \downarrow$ and $\mathrm{S}^{*}$ was the strongest in summer months, whereas for $\mathrm{L} \downarrow$ and $\mathrm{L}^{*}$, the correlation was opposite. Especially from November until March, when the frequency of low-level sheet clouds was greater (Wójcik and Uscka 1999), L $\downarrow$ increased. The longwave balance $\mathrm{L}^{*}$ assumes the lowest values in overcast weather. A clear sky favours greater emittance of longwave radiation. The correlation of $\mathrm{Q}^{*}$ and cloudiness is not unambiguous: with limited cloudiness large quantities of $\mathrm{S} \downarrow$ reach the ground surface and the balance of $\mathrm{S} *$ is greater but, simultaneously, outgoing longwave radiation increases, which leads to greater energy losses $\left(\mathrm{L}^{*}\right)$ and a reduction in $\mathrm{Q}^{*}$. A strong correlation between $\mathrm{Q}^{*}$ and cloudiness was typical of summer and winter, but in the months when the value of Q* was around zero, the correlation was weak.

A statistically significant correlation was found between the components of $\mathrm{Q}^{*}$ and atmospheric circulation, in particular the type of barometric centre and the properties of incoming air masses. It was established that the greatest values of $Q^{*}$ at Koniczynka occurred with anticyclonic synoptic situations $\left(5.76 \mathrm{MJ} \cdot \mathrm{m}^{-2} \cdot \mathrm{day}^{-1}\right)$, whereas with cyclonic types, they are smaller $\left(4.05 \mathrm{MJ} \cdot \mathrm{m}^{-2} \cdot \mathrm{day}^{-1}\right)$. Anticyclones were accompanied by smaller cloudiness, which enabled a large influx of $\mathrm{S} \downarrow$ (on average $12.13 \mathrm{MJ} \cdot \mathrm{m}^{-2} \cdot \mathrm{day}^{-1}$ ), while in cyclonic situations, it was only $8.82 \mathrm{MJ} \cdot \mathrm{m}^{-2} \cdot \mathrm{day}^{-1}$. The differences were reduced by longwave radiation balance $\mathrm{L}^{*}\left(-4.04 \mathrm{MJ} \cdot \mathrm{m}^{-2}\right.$. $\mathrm{day}^{-1}$ ), unfavourable for anticyclonic weather, which amounted to $-3.10 \mathrm{MJ} \cdot \mathrm{m}^{-2} \cdot \mathrm{day}^{-1}$ in cyclonic weather. There were bigger disparities between individual types of synoptic situations, and they became even wider in specific seasons depending on the direction of advection of air masses.

The issue of trends observed in individual components of $Q^{*}$ has been extensively discussed in the literature. Most works concern $\mathrm{S} \downarrow$. Initially, a reduction was observed in the amount of solar radiation reaching the Earth's surface, connected with growing atmospheric pollution; the phenomenon was dubbed "global dimming". In the 1980s, the trend reversed and "global brightening" began (Wild 2009). In the years 1987-2002, Europe witnessed an increase in the amount of incoming shortwave radiation, $\mathrm{S} \downarrow$, reaching $1.0 \%$ per decade (Norris and Wild 2007); then, it accelerated to $2.2 \%$ per decade in 1985-2005 (Wild et al. 2009). The trend was verified by observations carried out using satellites. In 1984-2000, the trends of $\mathrm{S} \downarrow$ and $\mathrm{S}^{*}$ were 2.4 and $2.2 \mathrm{Wm}^{-2}$ per decade, respectively (Hatzianastassiou et al. 2005), and in 1983-2015, they were 1.9 and $2.4 \mathrm{Wm}^{-2}$ decade $^{-1}$ (Pfeifroth et al. 2018). In Poland, also, growing trends in the amount of incoming solar radiation are observed (Uscka-Kowalkowska et al. 2007). Kleniewska and Chojnicki (2016) found that in Warsaw in the years 1964-2013, a falling trend occurred at first, but then — after 1981 - there was a rise in $\mathrm{S} \downarrow$; all in all, in the most recent half century, the trend reached $11.4 \mathrm{MJ} \cdot \mathrm{m}^{-2}$. year. Similarly, in Kołobrzeg in the north of Poland, this kind of pattern was observed (Kleniewska et al. 2016). It seems to be a result of reduced cloudiness in Poland, which in 19712000 exhibited varied trends, though most were downward (Filipiak and Miętus 2009).

The short span of observations (2011-2018) does not enable analysis of the trends of the components of $\mathrm{Q}^{*}$ at Koniczynka. However, the obtained values are clearly higher than those contained in the $20^{\text {th }}$ century data sources, such as maps of the distribution of annual sums of $\mathrm{S} \downarrow$ in Poland in the years 1961-1995 (Bogdańska and Podogrocki 2000) and the Climate Atlas of Poland (Lorenc 2005). Previous research conducted at Koniczynka (Kejna et al. 2018) indicated a statistically significant trend of $\mathrm{S} \downarrow$ reaching $13.6 \mathrm{MJ} \cdot \mathrm{m}^{-2}$.year ${ }^{-1}$ in 2003 2016. The cause of the changes in Poland and Europe may be multiple: atmospheric circulation (e.g. the North Atlantic Oscillation [NAO] - Bryś and Bryś 2019), changes in the cloud amount (Russak 1990; Stjern et al. 2009; Chiacchio et al. 2010; Matuszko 2014) or in the optical thickness of clouds (Liepert 2002), content of total precipitable water (Hatzianastassiou et al. 2005) or atmospheric transparency (Uscka-Kowalkowska 2013). Reduced cloudiness affects the other components of the balance $\mathrm{Q}^{*}$; for example, in southwestern Poland, there was a falling trend in $\mathrm{L}^{*}$ calculated on the basis of cloudiness (Brunt formula) (Bryś et al. 2019).

Moreover, the extinction of solar radiation is caused by aerosol emissions. In Europe, near-surface total mass concentration of sulphate, black carbon and primary organic carbon had a $62 \%$ decrease during 1980-2018. The decrease in sulphate loading leads to a warming effect of $2.0 \mathrm{~W} \mathrm{~m}^{-2}$ in Europe (Yang et al. 2019). Nevertheless, there is still a lot of air pollution in urban areas, resulting in reduced $\mathrm{S} \downarrow$, e.g. by $-9.1 \mathrm{MJ} \cdot \mathrm{m}^{-2} \cdot 10$ years in Kraków in 1884-2010 (Matuszko 2014), or by $-1.95 \mathrm{MJ} \cdot \mathrm{m}^{-2} \cdot 10$ years in Wrocław-Swojec in 1875-2004 (Bryś and Bryś 2007; Bryś 2009).

The observed substantial variability of Q* at Koniczynka is determined by cloudiness and atmospheric circulation. The solar energy feeding into the ground and atmosphere affects the functioning of the entire climate system. In nearby Torun, a correlation between the increase in air temperature and the intensity of solar radiation, especially in the summer season was observed (Kejna and Rudzki 2021). 
Acknowledgements This study was carried out as a part of the Integrated Environmental Monitoring Project funded by Polish Inspectorate of Environmental Protection.

Author's contributions Study design: Marek Kejna, Joanna UsckaKowalkowska; data collection: Marek Kejna; Joanna UsckaKowalkowska; statistical analysis: Marek Kejna, Paweł Kejna; result interpretation: Marek Kejna, Joanna Uscka-Kowalkowska; manuscript preparation: Marek Kejna; literature review: Marek Kejna.

Funding The research was carried out under the Integrated Environmental Monitoring Project funded by Polish Inspectorate of Environmental Protection and Fund for Basic Research Activities of the Faculty of Earth Sciences and Spatial Management, Nicolaus Copernicus University, Torun, Poland.

Data availability The data used in this study are available in the Integrated Environmental Monitoring database http://centrumzmsp. home.amu.edu.pl (the program coordinator's consent to disclose the data is required) and on the website of the Institute of Meteorology and Water Management https: // danepubliczne. imgw.pl.

\section{Declarations}

Consent for publication I consent to the publication of the article entitled "The influence of cloudiness and atmospheric circulation on radiation balance and its components" by Marek Kejna, Joanna UsckaKowalkowska, Paweł Kejna in the journal Theoretical and Applied Climatology

Conflict of interest No potential conflict of interest was reported by the authors.

Open Access This article is licensed under a Creative Commons Attribution 4.0 International License, which permits use, sharing, adaptation, distribution and reproduction in any medium or format, as long as you give appropriate credit to the original author(s) and the source, provide a link to the Creative Commons licence, and indicate if changes were made. The images or other third party material in this article are included in the article's Creative Commons licence, unless indicated otherwise in a credit line to the material. If material is not included in the article's Creative Commons licence and your intended use is not permitted by statutory regulation or exceeds the permitted use, you will need to obtain permission directly from the copyright holder. To view a copy of this licence, visit http://creativecommons.org/licenses/by/4.0/.

\section{References}

Bogdańska B, Podogrocki J (2000) Zmienność całkowitego promieniowania słonecznego na obszarze Polski w okresie 19611995. Materiały Badawcze, Meteorologia, 30. IMGW, Warszawa, pp 1-43 (in Polish)

Bokwa A, Matuszyk K (2007) Zmiany promieniowania całkowitego w Krakowie i Gaiku-Brzezowej. Pamiętnik Puławski 144:5-12 (in Polish)

Bryś K (2009) Zmiany bilansu promieniowania powierzchni bez roślin i porośniętej trawą we Wrocławiu-Swojcu. Acta Agrophysica 14(2): 287-302 (in Polish)

Bryś K (2013) Dynamics of net radiation balance of grass surface and bare soil. University of Environmental and Life Science Publish. Monographs CLXII, Wrocław
Bryś K, Bryś T (2003) Fluctuations of global solar radiation in 20th century at Wrocław and their relations to Wolf's number and circulation changes. Acta Univ Wratisl St Geogr 2542(75):189-202

Bryś K, Bryś T (2007) Zmienność klimatu solarnego Wrocławia w latach 1875-2004. Pamiętnik Puławski, 144, IUNiG, Puławy:13-33 (in Polish)

Bryś K, Bryś T (2019, 2019) Multi-annual variability of global solar radiation in the agricultural part of Lower Silesia (SW Poland) and its relationship to the North Atlantic Oscillation. Meteorol Hydrol Water Manag 7(2):13-25. https://doi.org/10.26491/mhwm/10346

Bryś K, Bryś T, Głogowski A (2019) Long-wave radiation balances of the south-west Poland. E3S Web of Conferences 116, 00013, https:// doi.org/10.1051/e3sconf/201911600013

Bryś K, Bryś T, Ojrzyńska H, Sayegh MA, Głogowski A (2020) Variability and role of long-wave radiation fluxes in the formation of net radiation and thermal features of grassy and bare soil active surfaces in Wrocław. Sci Total Environ 747:141192. https://doi.org/ 10.1016/j.scitotenv.2020.141192

Budzik T (2006) Pomiary promieniowania krótkofalowego i długofalowego w Sosnowcu w latach 2002-2005 z wykorzystaniem bilansomierza CNR-1 (Net Radiometr Kipp \& Zonen). Annales Universitatis Mariae Curie-Skłodowska, Geographia, Sectio B, LXI: 100-106

Caputa Z, Leśniok M (2009) Struktura bilansu promieniowania na obszarach miejskich i wiejskich - system pomiarowy i wybrane wyniki pomiarów na Wyżynie Śląsko-Krakowskiej. Prace Geograficzne UJ 122:23-38 (in Polish)

Caputa Z, Wojkowski J (2009) Struktura promieniowania w pełnym zakresie widma na obszarze Ojcowskiego Parku Narodowego, Prądnik. Prace i Materiały Muzeum im. prof. Władysława Szafera 19:119-140 (in Polish)

Chiacchio M, Ewen T, Wild M, Arabini E (2010) Influence of climate shifts on decadal variations of surface solar radiation in Alaska. $\mathrm{J}$ Geophys Res 115(D10). https://doi.org/10.1029/2009JD012533

Filipiak J, Miętus M (2009) Spatial and temporal variability of cloudiness in Poland,1971-2000. J Climatol 29:1294-1311. https://doi.org/10. $1002 /$ joc. 1777

Fortuniak K, Pawlak W, Siedlecki M, Zieliński M (2015) Urban-rural differences in longwave radiation - Łódź case study. ICUC9 - 9th International Conference on Urban Climate jointly with 12th Symposium on the Urban Environment

Hatzianastassiou N, Matsoukas C, Fotiadi A, Konstantinos G, Pavlakis E, Drakakis Hatzidimitriou D, Vardavas I (2005) Global distribution of Earth's surface shortwave radiation budget. Chemistry 5:28472867. https://doi.org/10.5194/acp-5-2847-2005

Kejna M, Rudzki M (2021) Spatial diversity of air temperature changes in Poland in 1961-2018. Theor Appl Climatol 143:1361-1379. https:// doi.org/10.1007/s00704-020-03487-8

Kejna M, Uscka-Kowalkowska J (2018a) Solar radiation variability at Koniczynka near Torun (Central Poland) in the years 2003-2016. Bulletin of Geography. Phys Geogr Ser 15:27-40. https://doi.org/ 10.2478/bgeo-2018-0013

Kejna M, Uscka-Kowalkowska J (2018b) Stan i przemiany środowiska przyrodniczego Geoekosystemu zlewni Strugi Toruńskiej. In: Kostrzewski A, Majewski M (eds) Stan i przemiany środowiska przyrodniczego geoekosystemów Polski w latach 1994-2015 w oparciu o realizację programu Zintegrowanego Monitoringu Środowiska Przyrodniczego. Biblioteka Monitoringu Środowiska, Warszawa, pp 193-235 (in Polish)

Kejna M, Uscka-Kowalkowska J, Araźny A (2014a) Bilans promieniowania w Koniczynce k. Torunia w latach 2011-2012. Przegl. Nauk. Inżynieria i Kształt. Środowiska 63:26-42 (in Polish)

Kejna M, Uscka-Kowalkowska J, Araźny A, Kunz M, Maszewski R, Przybylak R (2014b) Spatial differentiation of global solar radiation in Torun and its suburban area (central Poland) in 2012. Bull Geogr Phys Geogr Ser 7:27-56 
Kleniewska M, Chojnicki BH (2016) Zmienność całkowitego promieniowania słonecznego w Warszawie w latach 1964-2013. Acta Geogr Lodziensia 104:67-74 (in Polish)

Kleniewska M, Chojnicki BH, Acosta M (2016) Long-term total solar radiation variability at the Polish Baltic coast in Kołobrzeg within the period 1964-2013. Meteorol Hydrol 2:35-40

Kleniewska M, Mitrowska D, Chojnicki BH (2018) Monthly average daily diffuse solar radiation in Poland within the period 20052015. XLVIII Semin Appl Math 23. https://doi.org/10.1051/ itmconf/20182300020

Kossowski J, Łykowski B (2007) Sumy dzienne promieniowania słonecznego w okresie letnim w Felinie koło Lublina i ich związek z usłonecznieniem i zachmurzeniem. Szkoła Główna Gospodarstwa Wiejskiego 35:74-84 (in Polish)

Kozłowska-Szczęsna T (1973) Promieniowanie pochłonięte na obszarze Polski. Prace Geograficzne PAN 99:1-19 (in Polish)

Liepert BG (2002) Observed reductions of surface solar radiation at sites in the United States and worldwide from 1961 to 1990. Geophys Res Lett 29:61-1-61-4. https://doi.org/10.1029/2002GL014910

Lockwood M (2012) Solar influence on global and regional climates. Surv Geophys 33(3-4):503-534

Lorenc H (ed) (2005) Atlas klimatu Polski. Instytut Meteorologii i Gospodarki Wodnej, Warszawa (in Polish)

Matuszko D (2014) Long-term variability in solar radiation in Krakow based on measurements of sunshine duration. Int J Climatol 23(1): 228-234

Miara K, Paszyński J, Grzybowski J (1987) Zróżnicowanie przestrzenne bilansu promieniowania na obszarze Polski. Przegl Geogr 4:487509 (in Polish)

Mlynczak PE, Smith GL, Hollmann R (2011) Annual cycle of surface longwave radiation. J Appl Meteorol Climatol 50:1212-1224

Niedźwiedź T (1981) Sytuacje synoptyczne i ich wpływ na zróżnicowanie przestrzenne wybranych elementów klimatu w dorzeczu górnej Wisły, Rozprawy Habilitacyjne UJ 58, Kraków (in Polish)

Norris JR, Wild M (2007) Trends in aerosol radiative effects over Europe inferred from observed cloud cover, solar "dimming" and solar "brightening". J Geophys Res 112(D8):D08214. https://doi.org/10. 1029/2006JD007794

Oke TR (1996) Boundary layer climates. Routledge, London New York

Olecki Z (1986) On the components of the radiation balance in Cracow. Zesz Nauk UJ Pr Geogr 69:27-38

Paszyński J (1966) Atlas bilansu promieniowania w Polsce. Dok. Geogr. IG PAN, Warszawa (in Polish)

Paszyński J, Miara K, Skoczek J (1999) Wymiana energii między atmosferą a podłożem jako podstawa kartowania topoklimatycznego. Dok. Geogr., IG PAN, Warszawa (in Polish)

Pfeifroth U, Sanchez-Lorenzo A, Manara V, Trentmann J, Hollmann R (2018) Trends and variability of surface solar radiation in Europe based on surface- and satellite-based data records. J Geophys ResAtmos 123:1735-1754. https://doi.org/10.1002/2017JD027418

Podstawczyńska A (2007) Cechy solarne klimatu Łodzi, Acta Geogr. Lodziensia, Folia Geogr. Phys., 7 (in Polish)

Power H (2003) Trends in solar radiation over Germany and an assessment of the role of aerosols and sunshine duration. Theor Appl Climatol 76:47-63. https://doi.org/10.1007/s00704-003-0005-8

Przybylak R, Maszewski R (2009) Zmienność cyrkulacji atmosferycznej w regionie Bydgosko-Toruńskim w latach 1881-2005. Acta Agrophys 14(2):427-447
Russak V (1990) Trends of solar radiation cloudiness and atmospheric transparency during recent decades in Estonia. Tellus B 42(2):206210

Stjern CW, Kristjansson JE, Hansen AW (2009) Global dimming and global brightening - an analysis of surface radiation and cloud cover data in northern Europe. Int J Climatol 29(5):643-653

Szwed M, Pińskwar I, Kundzewicz ZW, Graczyk D, Mezghani A (2017) Changes of snow cover in Poland. Acta Geophys 65(1):65-76

Uscka J (2004) Przezroczystość atmosfery w strefie podmiejskiej Torunia w latach 1999-2001. In: Kejna M, Uscka J (eds) Zintegrowany Monitoring Środowiska Przyrodniczego. Biblioteka Monitoringu Środowiska, pp 177-186 (in Polish)

Uscka J, Wójcik G, Marciniak K, Kejna M (2001) Zachmurzenie i usłonecznienie w Koniczynce (Równina Chełmżyńska) w latach 1996-2000. Biblioteka Monitoringu Środowiska, Kielce, pp 117 126

Uscka-Kowalkowska J (2010) The oldest heliographic and actinometric measurements in Poland. Acta Agrophys Rozprawy i Monografie 5(184):24-34

Uscka-Kowalkowska J (2013) An atmospheric extinction of direct solar radiation on Mt. Kasprowy Wierch, Poland. Atmos Res 134:175185

Uscka-Kowalkowska J, Przybylak R, Vizi Z, Araźny A, Kejna M, Maszewski R (2007) Variability of global solar radiation in Central Europe, 1951-2005 (on the basis of data from NCEP/ NCAR Reanalysis). Geogr Pol:59-68

Uscka-Kowalkowska J, Kejna M, Maszewski R (2015) Wpływ cyrkulacji atmosferycznej na usłonecznienie w Koniczynce k/ Torunia w latach 1999-2013. Ann Univer Maria CurieSkłodowska Lublin-Polonia LXX 2B:131-147 (in Polish)

Wild M (2009) Global dimming and brightening: a review. J Geophys Res 114:D00D16. https://doi.org/10.1029/2008JD011470

Wild M, Trussel B, Ohmura A, Long CN, Konig-Langlo G, Dutton EG, Tsvetkov A (2009) Global dimming and brightening: an update beyond 2000. J Geophys Res 114(D10):D00D13. https://doi.org/ 10.1029/2008JD11382

Wild M, Hakuba MZ, Folini D, Dörig-Ott P, Schär C, Kato S, Long CN (2019) The cloud-free global energy balance and inferred cloud radiative effects: an assessment based on direct observations and climate models. Clim Dyn 52:4787-4812. https://doi.org/10.1007/ s00382-018-4413-y

Wójcik G (1996) Globalne promieniowanie słoneczne i jego transmisja przez atmosferę w Toruniu. Acta Univ Nicolai Copernici Geografia XXVII 97:65-73 (in Polish)

Wójcik G, Marciniak K (eds) (1996) Zintegrowany Monitoring Środowiska Przyrodniczego - Stacja Bazowa Koniczynka. Biblioteka Monitoringu Środowiska, Warszawa-Torun (in Polish)

Wójcik G, Uscka J (1999) Zachmurzenie w Toruniu w latach 1986-1995. Acta Universitatis Lodziensis. Folia Geogr Phys 3:251-263 (in Polish)

Yang Y, Lou S, Wang H, Wang P, Liao H (2019) Trends and source apportionment of aerosols in Europe during 1980-2018. Atmos Chem Phys. https://doi.org/10.5194/acp-2019-778

Yu H, Kaufman YJ, Chin M, Feingold G, Remer LA (2006) A review of measurement-based assessments of the aerosol direct radiative effect and forcing. Atmos Chem Phys 6(3):666 hal-00328420

Publisher's note Springer Nature remains neutral with regard to jurisdictional claims in published maps and institutional affiliations. 